\title{
Advances and insights in the diagnosis of viral infections
}

\author{
Julija Dronina ${ }^{1,2}$, Urte Samukaite-Bubniene ${ }^{2}$ and Arunas Ramanavicius ${ }^{2^{*}}$ (1)
}

\begin{abstract}
Viral infections are the most common among diseases that globally require around 60 percent of medical care. However, in the heat of the pandemic, there was a lack of medical equipment and inpatient facilities to provide all patients with viral infections. The detection of viral infections is possible in three general ways such as (i) direct virus detection, which is performed immediately $1-3$ days after the infection, (ii) determination of antibodies against some virus proteins mainly observed during/after virus incubation period, (iii) detection of virus-induced disease when specific tissue changes in the organism. This review surveys some global pandemics from 1889 to 2020, virus types, which induced these pandemics, and symptoms of some viral diseases. Non-analytical methods such as radiology and microscopy also are overviewed. This review overlooks molecular analysis methods such as nucleic acid amplification, antibody-antigen complex determination, CRISPR-Cas system-based viral genome determination methods. Methods widely used in the certificated diagnostic laboratory for SARS-CoV-2, Influenza A, B, C, HIV, and other viruses during a viral pandemic are outlined. A comprehensive overview of molecular analytical methods has shown that the assay's sensitivity, accuracy, and suitability for virus detection depends on the choice of the number of regions in the viral open reading frame (ORF) genome sequence and the validity of the selected analytical method.
\end{abstract}

Keywords: COVID-19, SARS-CoV-2 virus detection, Antibody-antigen complex, Immunosensors, Polymerase chain reaction (PCR), CRISPR-Cas for DNA-Sensors, Biosensors, Surface plasmon resonance (SPR), Photoluminescence

\section{Main}

Viral diseases are infections caused by different types of viruses. Viruses are structures of various microscopic sizes (from 20 to $900 \mathrm{~nm}$ ) and morphological forms, composed of genetic material, which can be positive or negative sense, single (ss) or double-stranded (ds) deoxyribonucleic acid (DNA) or ribonucleic acid (RNA), surrounded by a coating based on proteins, glycoproteins, or lipids [1]. Viruses themselves do not produce energy, do not increase and have a straightforward structure. Therefore, they can only grow in other living cells (host cells), suitable for hosting a particular virus type. Once

\footnotetext{
*Correspondence: arunas.ramanavicius@chf.vu.lt

${ }^{2}$ Department of Physical Chemistry, Faculty of Chemistry

and Geoscience, Vilnius University, Naugarduko str. 24, 03225 Vilnius, Lithuania

Full list of author information is available at the end of the article
}

a virus enters a cell (Fig. 1), it releases and integrates its genetic material within the host cell's genome and takes over these cell's functions, which are required for the proliferation of the virus. Besides, some infected cells are proliferating themselves and, at the same time, are multiplying the genome of the virus. When the host organism's immune system detects a virus, it starts to react in a particular way. One of such ways in mammalian organisms is producing specific antibodies that help neutralize the virus and the cells that are infected by the virus. Still, the host's organism is not always able to defend itself. However, it is essential to consider that all viruses develop very rapidly and are spread by the worldwide migration of living organisms.

Viruses constantly attack humankind. Over the last two centuries, a viral pandemic has posed an increasing threat to public health worldwide. From 1889 to original author(s) and the source, provide a link to the Creative Commons licence, and indicate if changes were made. The images or other third party material in this article are included in the article's Creative Commons licence, unless indicated otherwise in a credit line to the material. If material is not included in the article's Creative Commons licence and your intended use is not permitted by statutory regulation or exceeds the permitted use, you will need to obtain permission directly from the copyright holder. To view a copy of this licence, visit http://creativecommons.org/licenses/by/4.0/. The Creative Commons Public Domain Dedication waiver (http://creativeco mmons.org/publicdomain/zero/1.0/) applies to the data made available in this article, unless otherwise stated in a credit line to the data. 


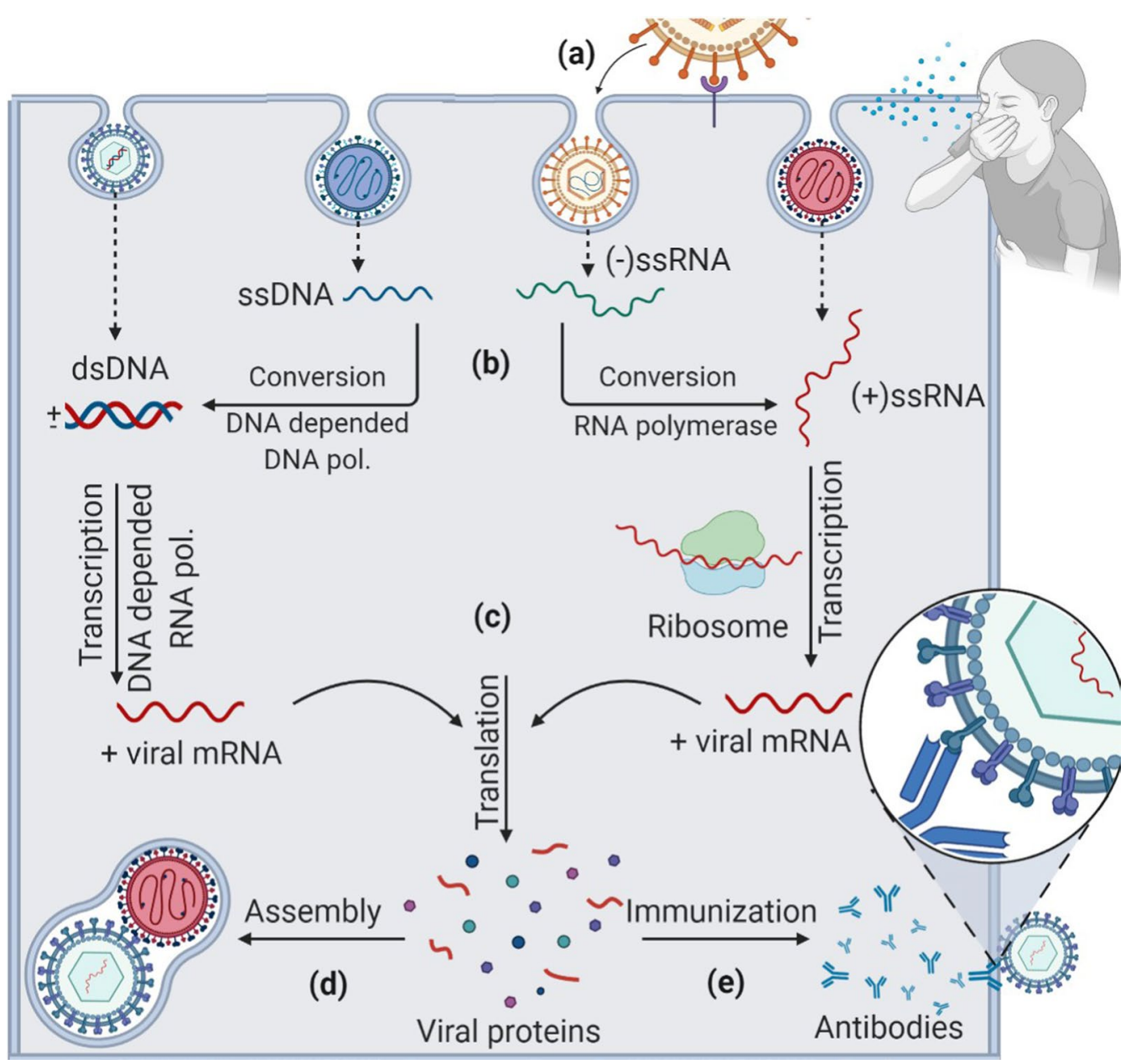

Fig. 1 The course of viral infection in the host cell. Viral infection in the human body begins when viral hemagglutinin protein (HA) (a) binds to a glycolipid receptor on the cell surface. It promotes the fusion of viral cell membranes with the host cell. Once a virus enters viral genetic material (b) into the host cell, its replicates, and mRNA (c) is synthesized and converted to viral proteins. RNA viruses (like flu, SARS-CoV-2) can use their RNA to directly create countless new viruses in the host cell. DNA viruses are always making RNA copies, but rarely reverse process is occuring. Except for some retroviruses (HIV/AIDS), they copy their RNA into DNA. mRNA takes over the cell's protein-making machinery to rapidly build a new amount of viruses. Subsequently, the synthesized viral genetic material and proteins are assembled (d) to form virions that help bud with neuraminidase (NA) and separate from the host cell. At the same time, the immunization takes place in the cell (e), the host cell begins to produce antibodies against the virus

the present, there have been several viral pandemics throughout human history. 1889-1890 the Asiatic flu pandemic killed about 1 million people worldwide [2, 3]. 1918-1920 the Spanish flu pandemic infected 20 to more than 50 million people [4]. Asian Flu in 1957-1968 has claimed from 500,000 to 2,000,000 human lives [5]. Since 1981 more than 85 mln Humans have been infected by Human Immunodeficiency Virus (HIV), more than 33 mln have died, and $7.1 \mathrm{mln}$ People at the end of 2019 are still living with acquired immunodeficiency syndrome (AIDS) but did not know that they have HIV infection (HIV, the virus that causes AIDS) [6]. World Health Organization (WHO) on 2020 March announced the outbreak of a Coronavirus disease 2019 (COVID-19) as a global pandemic causing Severe Acute Respiratory Syndrome Coronavirus-2 (SARS-CoV-2) [7, 8]. From 2020 until 2021, there are more than 86,000,000 confirmed cases of COVID-19, and more than 1.8 million human deaths have already been identified, and unfortunately, the number of cases is still rising $[9,10]$.

\section{Pandemics evolution history and studies}

The Asiatic flu pandemic of $1889-1890$ was quickly and in detail defined in the media of all the affected countries (France, Italy, Spain, Germany, Great Britain, Poland, Austria, Russia), and publications were 
mentioning not only statistics but also the symptoms of the disease and the strategy used to manage the pandemic. The origin of the Asiatic flu pandemic virus is still unknown, but it is hypothesized that the pandemic could be caused by the H3N8 virus $[11,12]$ or H2N2 virus $[13,14]$. The end of the one-year pandemic shows that isolating the population and restricting travel is a plausible way to fight the pandemic $[15,16]$ but shrinks the economies and cost people lives. The fight against Spanish flu in 1918-1920 was similar to the Asiatic flu epidemic: with no information on the virus's origin, no vaccine to protect against influenza infection, and no antibiotics to treat influenza infections [17]. Only control efforts worldwide have been limited to non-pharmaceutical interventions such as isolation, quarantine, good personal hygiene, use of disinfectants, and various social restrictions. Since 2004, tissue studies of the remains of people infected by 'Spanish flu' have been started. In the remains detected the origin of the H1N1 virus [18-21].

In the face of a pandemic, various technologies and strategies are being developed, focusing on an accurate diagnosis of a particular disease, epidemiological control security, and effective prevention of virus spread. Scientists, diagnostic, and pharmaceutical companies are working hard and collaborating to detect infections faster, more accurate, and cheaper. Therefore, it is essential to know virus sequences and molecular data to apply optimal virus detection methods. Virus detection methods must be of high quality, sensitivity, specific, and relatively simple in function. Analytical virus detection methods, general-purpose reagents, or equipment must be manufactured and validated following the regulatory compliance and quality assurance (QA) rules of the International Organization for Standardization (ISO) [22, 23]. The most critical tasks and research directions during the development of bioanalytical systems for reliable determination of viral infections are:

- the release of virus or it's genetic information from a particular matrix type,

- the development of molecular and non-molecular virus detection methods,

- the improvement of bioanalytical methods for the determination of specific antibodies against viral proteins and other virus-related structures.

The work aims to describe the validated methods used in the world market to detect SARS-CoV-2, Influenza $\mathrm{A}, \mathrm{B}$ and $\mathrm{C}, \mathrm{HIV}$, and other viruses, to determine the dependencies of the methods and results, to provide insights.

\section{Challenges and opportunities}

With experience from previous pandemics and other infections, it is possible to respond correctly to the spread of some viruses. The global COVID-19 [24] pandemic has revealed a lack of tools and skills in treatment facilities to detect infectious diseases leading to delays in diagnosis and/or arrangement of a particular treatment for large quantities of patients. For COVID-19 detection, selected rapid commercial tests have been approved by the Emergency Use Authorization (EUA), the U.S. Food and Drug Administration (FDA) and are CE marked (CE - administrative marking that indicates conformity with health, safety, and environmental protection standards for products sold within the European Economic Area (EEA) and outside of the EEA [25]. The list of rapid tests includes antibody-antigen complex formation based detection IgG/IgM [26], multiplex polymerase chain reaction (automated polymerase chain reaction (PCR) systems that can run over 100 tests per day), isothermal polymerase chain reaction, DNA Endonuclease-Targeted CRISPR Trans Reporter technique based on CRISPRCas12 (DETECTR) [27], Specific High Sensitivity Enzymatic Reporter unlocking platform with CRISPR Cas12 and Cas13 enzymes (SHERLOCK) methods [28]. However, the most sensitive, widely used, but long-lasting and additional equipment-based real-time or quantitative polymerase chain reaction (real-time PCR) methods are the most commonly used to diagnose viral and other pathogen infections [29]. The determination of the SARS-Cov- 2 virus by polymerase chain reaction is based on several steps:

- Viral RNA is purified from tissue or blood samples. Reverse transcription reaction is performed to obtain cDNA [30] from viral RNA.

- Genetic material is amplified by polymerase chain reaction (PCR). The data analysis is performed. The entire process takes more than $2 \mathrm{~h}$ [31].

Some alternative innovative technological solutions are being sought to maintain the sensitivity of real-time PCR but to shorten the time from sampling to detection. However, to eliminate the gel electrophoresis step in analytical methods, DNA fragments can be identified by DNA sensors [32-34]. Even more advanced PCR-method is based on the real-time reverses-transcriptase polymerase chain reaction (real-time RT-PCR) method is more widely used today to detect COVID-19. The technique uses complex mixtures of enzymes (DNA polymerases, reverse transcriptases, nucleotides, etc.), shortening the processing time. Virus sequence detection by real-time RT-PCR is further developed to speed up virus detection. New technological achievements enable the facilitation 
of molecular tests or fully automated systems to simplify testing and allow a large number of samples to be tested simultaneously. New RT-PCR-based methods are also being developed to detect multiple pathogens at the same time.

Unfortunately, the choice of virus or disease detection method depends on many factors such as the nature of the virus, the affected area, the activity and viability time on different surfaces, or the virus incubation period (Fig. 2) [35]. As mentioned in many sources, viral diseases that directly affect the organs, such as COVID-19 viral disease does [36-38], or an infectious disease caused by the hepatitis $\mathrm{C}$ virus ( $\mathrm{HCV}$ ) (Hepatitis C) [39] are possibly better diagnosed using radiological images. However, the primary intention is to detect the virus in the organism as soon as possible and apply effective treatment. For example, direct amount of SARS-CoV-2 virus from the respiratory tract is exponentially dependent on the incubation period (the period from infection to onset of symptoms), and viability differs from the nature of surfaces (about $72 \mathrm{~h}$ on plastic, $4-8 \mathrm{~h}$ on copper, $8-24 \mathrm{~h}$ on cardboard, and $3 \mathrm{~h}$ on aerosol particles) as well [40, 41]. The knowledge about various virus incubation periods helps select appropriate methods for virus detection. Information on the incubation period of the virus in the host cell can help identify risk periods and local transmission and spread of the virus. For most acute infections, the virus is extracted at peak titers in the late stages of the incubation period before the host immune response has been established [42]. In COVID-19, due to the short incubation period of the virus, patients should be sampled from the upper respiratory tract (URT) and lower respiratory tract (LRT) on days 2 and 3 of symptoms, respectively, to directly detect the SARS-CoV-2 virus in the body. Extensive research has shown [43-45]. From day 3 to day 5 , the amount of virus in the LRT sample increased. Here important to note that, in the URT and LRT samples, the viral load decreased from about day 7 , and from day 13 , the viral load was no longer detectable by RT-PCR or real-time RT-PCR. However, after 13 days, the serological antibody assay by RT-PCR or real-time RT-PCR shouldn't be performed. Unfortunately, clinical cases of COVID-19 range are from asymptomatic to fever with mild respiratory disease, and even acute respiratory distress syndrome and death from respiratory failure or related complications [46]. When it is difficult for patients to determine the actual date of onset of infection, it would be best to follow the results of several methods.

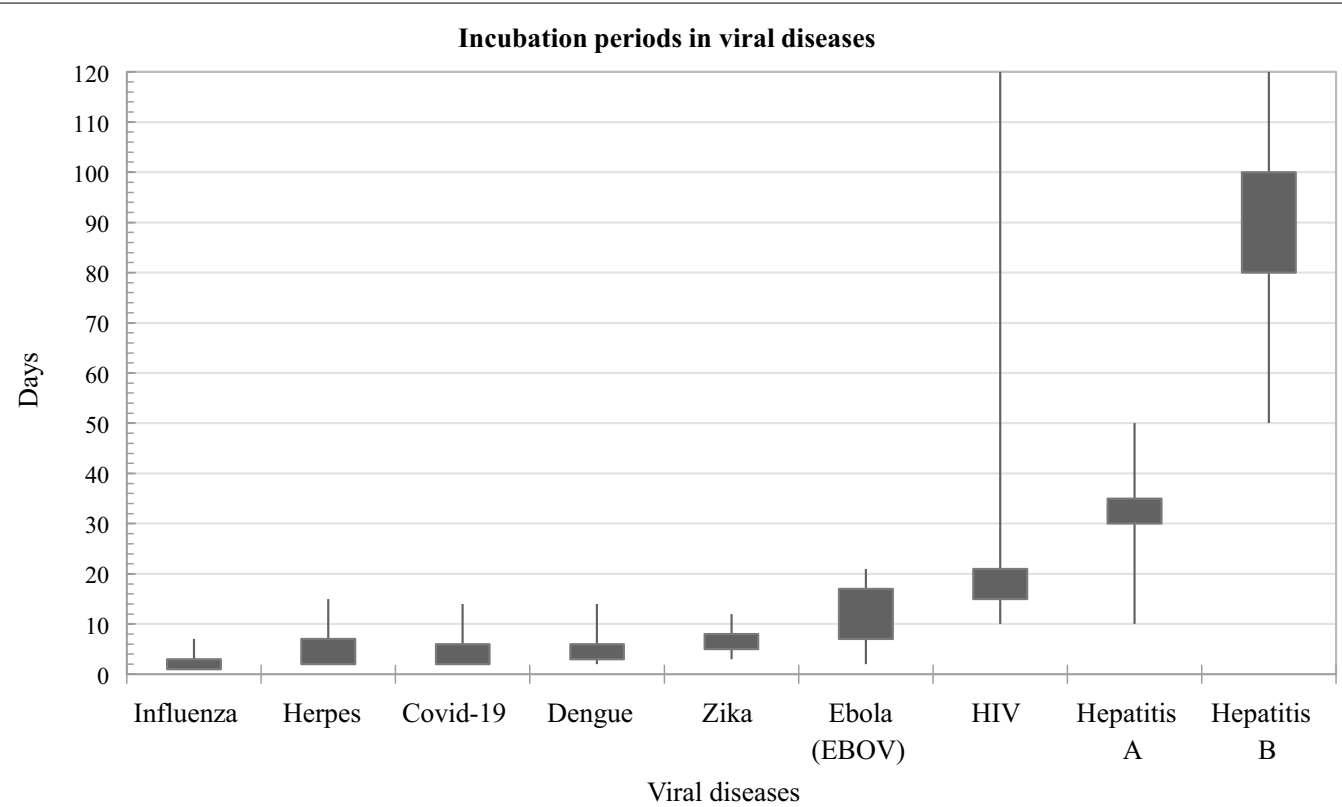

Fig. 2 The range and the most common incubation periods in viral diseases. For influenza the most common virus incubation period in the host is 1-3 days; Herpesvirus 2-7 days; Covid-19 2-5 days [47-51]; Dengue 3-6 days [52-55]; Zika 5-8 days [56-59]; Ebola virus 7-17 days [60-63]; HIV 5-21 days; Hepatitis A 30-35 days [64, 65]; Hepatitis B 80-100 days [66-70]. In the case of COVID-19, the likelihood of detecting the virus from the respiratory tracts is likely to be $2-5$ days after possible infection. Seven days after the onset of symptoms, the chance of detecting the virus directly from the respiratory tract decreases 


\section{Molecular and non-molecular virus detection techniques}

Virus detection methods can be divided into two groups (Fig. 3) molecular and non-molecular detection techniques. Assays for developing antibodies against the virus using immunofluorescence or conjugates of immune enzymes, enzyme-linked immunosorbent assay (ELISA), and serological tests, or direct detection of the virus by nucleic acid amplification methods are currently widely used. However, the American Society of Infectious Diseases (IDSA) and World Health Organization (WHO) recommends to apply molecular detection methods for direct virus detection [71], while some other methods also can be used for research, investigation, or the collection of additional domains.

\section{Non-molecular virus detection methods}

The first discovered virus was the tobacco mosaic virus (TMV) in 1882, invented by Iwanowski [72]. He and colleagues showed that extracts of diseased tobacco plants pass through filters that trap bacteria, but the plant still transmitting diseases to other plants. Until 1930 scientists hypothesized that the non-bacterial pathogen of tobacco mosaic disease consists of protein and nucleic acids [73-76]. The first tobacco mosaic virus particles (TMV) were visually identified after the invention of the electron microscope (EM) in 1931 by Ruska [77]. In 1935 the purification and crystallization of the tobacco mosaic virus protein were performed by Stanley [78]. Besides, in 1946 author received a part of the Nobel Prizes in Chemistry award for the crystallization of tobacco mosaic virus [79], that innovation allowed the use of molecular analytical methods. Wendell M. Stanley identified that plant viruses consist of two substances (protein and nucleic acid-RNA) and give high yields of the active virus. High results of active viruses confirm that viral genome replication occurs only within living (host) cells, and studies by other authors have confirmed these claims [80-83]. The visualization of the tobacco mosaic virus was established by X-ray diffraction in 1978 [84-87]. 1960-1990 the nucleic acid (RNA) of the tobacco mosaic virus (TMV) was sequenced [30, 88-93]. Because the tobacco mosaic virus is a single-stranded RNA virus, oligonucleotide primers were used to generate cDNA and encode the RNA sequence. The virus sequencing in 1982 resulted in a fully characterized library of phages, which were later used as a single-chain source for hybridization experiments and site-directed mutagenesis, as well as antiviral techniques. 1989 Powell et al. studies have shown that the accumulation of antisense RNA complementary to the tobacco mosaic virus sequence and the 3' non-coding region protects the plants from infection [94, 95].
Grafting [96, 97], epigenetics [98, 99], transgenetic [100], and other technologies have been studied to increase the resistance of plants not only to viruses but also to adverse environmental conditions.

\section{Electron microscopy based virus detection}

Transmission electron microscopy (TEM) is the only technique that can provide simple, fast, and clear morphological images of the virus [101] and differential diagnosis of different agents. The use of electrons for imaging allows a resolution of about $0.2 \mathrm{~nm}$ to be achieved, which can be used for visualization macromolecules such as capsid proteins or viral nucleic acids. The electron beams are generated using TEM analysis by either tungsten or LaB6 filament or field emission gun. Monochrome electron beam for biological work in a vacuum accelerates through 40-100 kV voltage and passes through magnetic fields that act as lenses. These electromagnetic fields are generated by solenoids that can concentrate the electron beam. Successful virus diagnosis by transmission electron microscopy is highly dependent on collection methods and sample preparation. Due to the low mass density, the biological structure (carbon, nitrogen, hydrogen) interacts weakly with the electrons used for imaging and therefore has low contrast or detail. TEM's main advantage is that it creates adequate virus image contrast and resolution. The biological fluids samples can be easily and quickly tested by positive or negative staining. There are two main differences between positive and negative staining. First, the positive staining technique (fixation, post-fixation, embedding resins, multiple staining incubation about four days) is about 500 times longer than the negative staining technique (about $10 \mathrm{~min}$ ). Second, the final virus image is darker formed against a light background (positive), unlike negative staining when a bright picture of the virus particle is formed against a dark background [102]. The negative staining technique from liquid viral samples, based on the deposition of viruses on carbon-coated grids and stained with heavy metals salts (e.g., lead, tungsten, and uranium ions are used in both staining techniques) used widely. Freezing or formalizing samples is a common mistake in TEM practice [103-106].

The minimum virus concentration required for successful morphologic identification by TEM is about $10^{6}-10^{7}$ particles/ml [107-109]. Since the sample may contain small amounts of virus particles, samples should be concentrated before virus detection to avoid false-negative results [110,111]. Widely used concentration sampling methods as (i) ultracentrifugation/ultrafiltration [112, 113], (ii) adsorption-elution [114-116]. Differences between concentration methods are detailed by Pasquale et al. [117] The main advantage of the ultracentrifugation 


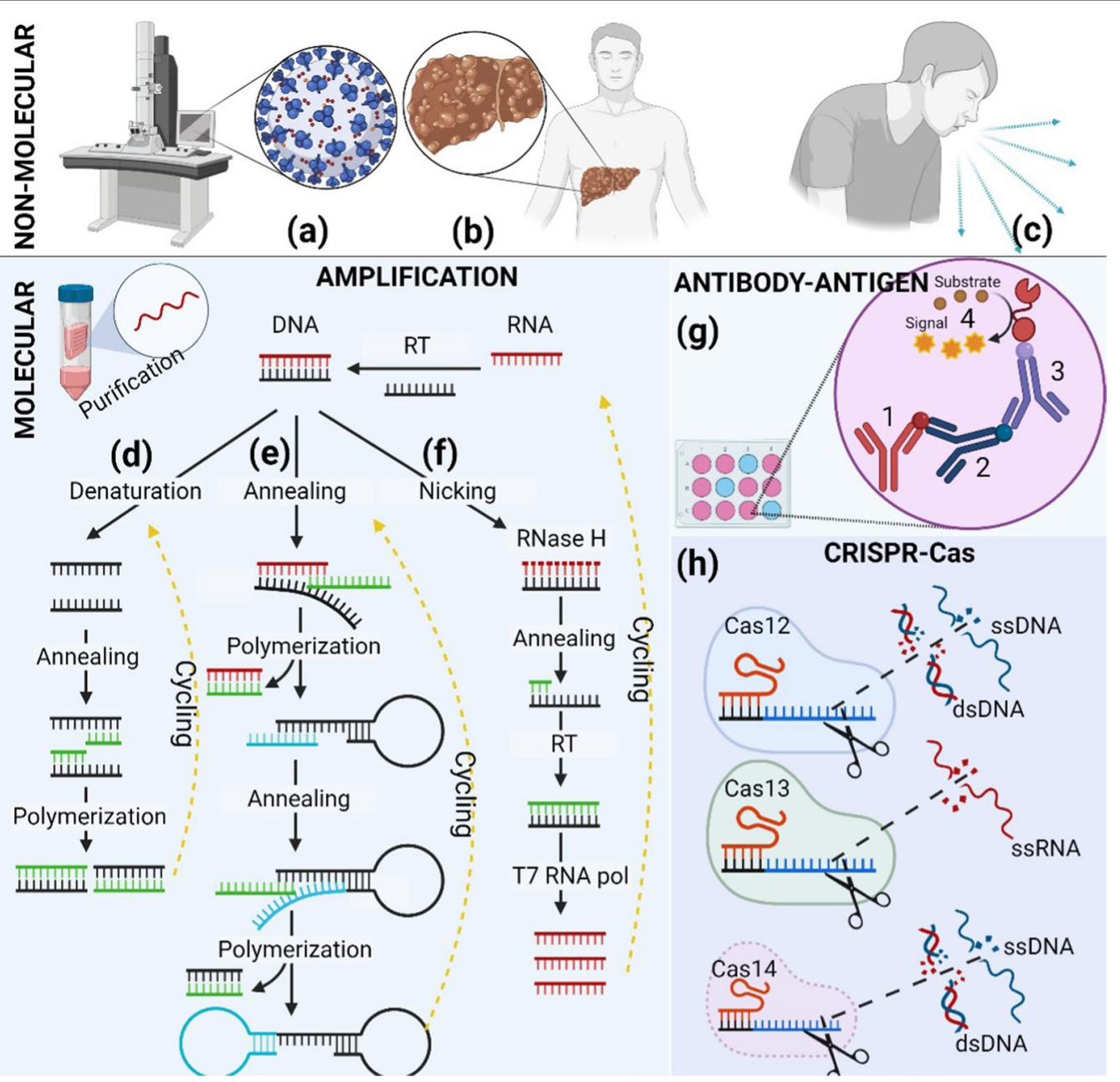

Fig. 3 Differences between molecular and non-molecular detection methods. The main application of non-molecular detection is to study the morphology (a electron microscopy) of the viruses or to determine (b X-ray detection) the symptoms of the viral (c visual symptoms detection) disease. However, in molecular diagnostics, a nonspecific reaction (cutting, multiplication, amplification, etc.) or other changes must occur after the target reaction. If the method is not nonspecific, such reactions use additional components that play the role of non-specificity. Also, the purification of nucleic acids is recommended in the use of molecular applications. Nucleic acid amplification increases the amount of DNA or RNA by cyclical repeating of some procedures. In the case of PCR, real-time PCR (d), and loop-mediated isothermal amplification (LAMP) (e) methods, both a DNA and an RNA fragment can always be used for the analyte, and after amplification, the final product is always a large amount of DNA. However, nucleic acid sequence-based amplification (NASBA) (f) applies only to RNA detection, and the uniqueness of the method, that after the cyclic reaction, contains DNA and RNA fragments in the mixture. An enzyme-linked immunosorbent assay (ELISA) is a method that uses a solid-phase-type enzyme-linked enzyme to detect a ligand in a liquid sample using antibodies directed against the protein being measured. The ELISA method is based on a stepwise, sandwich-based combination: 1—capture antibody; 2—antibody detection; 3—secondary antibody conjugation; 4-enzymatic conversion from enzyme to colorimetric or photoluminescence substrate signal. However, fluorescent ELISA usually utilizes secondary antibodies conjugated with a fluorophore. The only drawback is the multilevel application. $\mathbf{h}$ Cas12, Cas13, and Cas14 are members of proteins used in CRISPR diagnostics. Cas12, Cas13, and Cas14 proteins are on the larger side of the CRISPR diagnostic protein. Cas 12 and Cas 14 proteins bind directly to the recognized he protospacer adjacent motif (PAM) site and cleave specified DNA sequences. After target cleavage, the Cas 12 and Cas 14 proteins begin to shred single-stranded DNA nonspecifically. The differences between Cas12 and Cas14-are the size of the protein and RNA length for target binding. The Cas 12 protein is 1300 amino acids, and the Cas 14 protein is approximately $400-700$ amino acids in length. Cas 12 DNA targets using 42-44 bp-however, Cas 14 protein 140 bp RNA molecules length. The shorter protein spends, the fewer resources are required to obtain the Cas14 protein in the laboratory, and the more extended RNA molecular sequence of the target indicates more excellent fit and accuracy but higher costs. In RNA detection, the technique must combine Cas 12 and Cas 14-based diagnostics with proteins that convert RNA to DNA. The Cas13 protein directly binds and cleaves specified RNA sequences, and protein can directly detect RNA but not DNA. The Cas 13 protein is 1400 amino acids in length, and the RNA guide molecule is relatively short at $\sim 64 \mathrm{bp}$. Thus, more resources are needed to produce Cas13-based detectors, additional Cas 13 does not have strict application restrictions, but RNA targets can accept structures that are difficult to cut due to structural limitations. More detailed differences are given in separate article sections and Table 1 


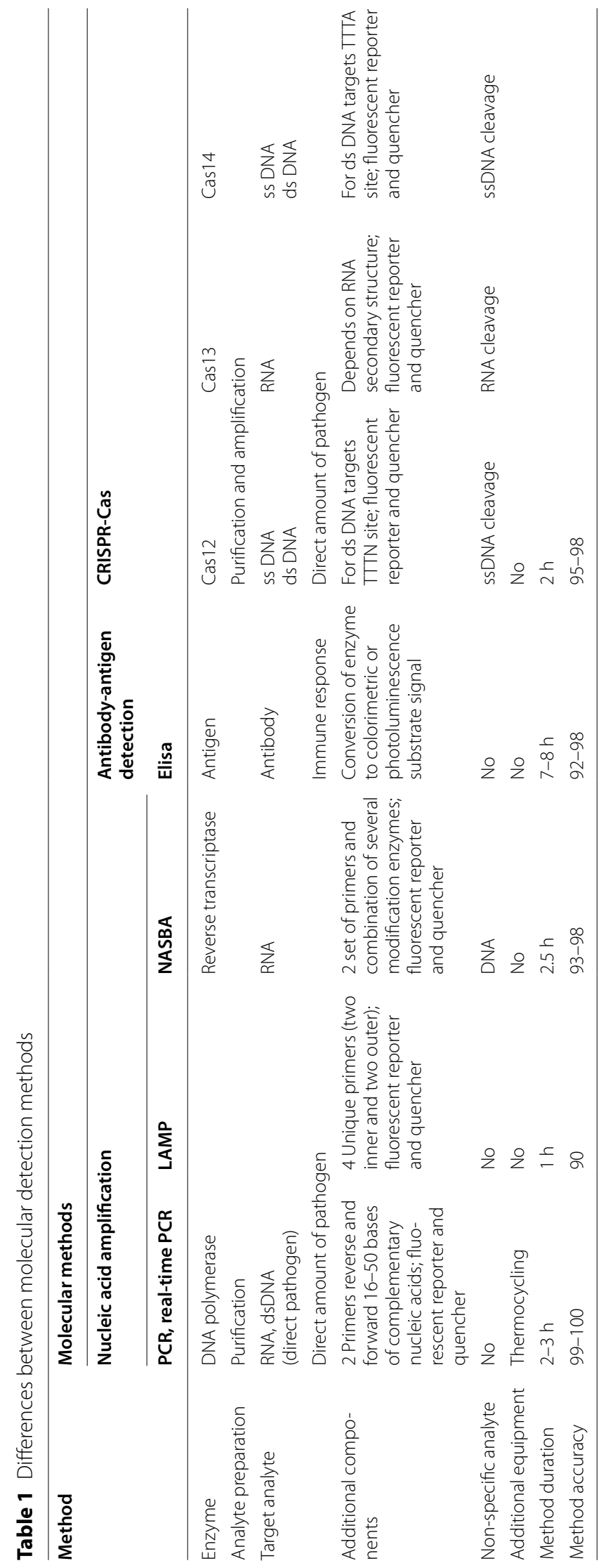


method is that it is possible to concentrate all viruses in a sample. The method requires minimal sample manipulation (processed under natural $\mathrm{pH}$ ), short processing time. Additional benefits are that the ultracentrifugation method achieved higher results than the adsorptionelution method, and equipment is often found in shared laboratories. During one of these procedures, the enrichment viral particles concentration will be approximately 5-100 times higher [118, 119]. Furthermore, virus inactivation, removal of inhibitors, and detection of specific viruses are essential points in detection. The authors did not consider the possibility and combination of using the electron microscopy method and molecular methods.

However, the benefits of TEM in addressing diagnostic problems in clinical virology have been demonstrated in the 1970s and 1980s, when the technique helped discover many clinically essential viruses such as adeno-, entero-, paramyxo-, and retroviruses. Identification and investigation of the morphology (differences in virus size and delicate structure) and the number of total particles (whether or not they are infectious) of all these viruses by TEM helped to more accurate classification of viruses. The main disadvantages of virus detection by the TEM method are particle counting-when counting manually in several grid elements simultaneously, this method is not very accurate. However, by TEM technique can incorrectly identify viruses with similar morphology. However, the advantage of the TEM method is its affordable application to "dirty" clinical samples such as plasma, urine, feces, or to detect the growing virus using cell culture (embryonated egg or laboratory animals). TEM turns out to be necessary to detect and identify a new (a morbillivirus virus [120], swine flu [121], bird flu [122], Ebola virus [123], SARS-CoV-2 [124]) type of viruses. In addition, details of the viral structure may be even more visible if viral preparations are rapidly frozen and vitrified samples are investigated by cryo-EM [125].

TEM analysis has long been a primary quantitative method for counting individual viral virion particles. Advances in microscopy and technology in virology have led to the development of quantitative analysis of viral particles [126]. The technologies include atomic force microscopy (AFM) [127], laser light application multi-angle laser light scattering (MALLS) $[128,129]$ or nanoparticles tracking analysis (NTA) [130-132] combines resistive impulse sensing (TRPS, method based on Coulter principle) and flow cytometry (FC) variants. The molecular techniques with the advantages of higher sensitivity, no sample concentration, and the ability to quickly process large volumes of samples have replaced TEM in many areas of virologic diagnostics. For virions of viral particles larger than $40 \mathrm{~nm}$, quantitative TEM estimation of viral particles is most commonly used, whereas quantification of viruses of small viruses (less than $40 \mathrm{~nm}$ ) is often performed using real-time RT-PCR $[126,128,133]$. Real-time RT-PCR results may be incorrect because the number of viral genomes does not necessarily correspond to the number of virions. There are results [109] that show a reasonable accuracy of the TEM quantification method even at a virion size of $30 \mathrm{~nm}$, but this is probably only due to the purification of the virus suspension before the TEM assay.

\section{Radiology based virus detection}

The use of X-ray microscopy is another powerful alternative to non-molecular virus detection tools based on the high penetration power of soft X-rays in the photon energy range of the water window (photon energy of $250 \mathrm{eV}$ ) in hydrated biological material (sample thickness $\leqslant 10$ microns) [134]. The use of diffraction optics in X-ray microscopes with cryogenic samples allowed the successful imaging of 3-D cells at 20-30 $\mathrm{nm}$ resolution [135].

Computed tomography is another tool that describes a fast scan time and a clear image for treating various viral diseases. Unfortunately, there are changes in the organs as the viral illness progresses. In the early stage, pneumonia [136-139] shows several small patches and interstitial changes in the lungs. Liver fibrosis is a disease caused by the hepatitis $C$ virus that complicates all liver processes. Fibrosis results in cirrhosis, which irreversibly destroys the liver [140, 141]. Changes in the liver can also be detected quickly by computed tomography. Examination, detection, and visualization of infected organs by computed tomography have become an indispensable tool for characterizing the early stages of viral infection and monitoring and assessing the severity of the disease. By the way, the clear damaged organ image can also be a significant warning signal for negative results obtained by the molecular virus detection methods (false-negative results).

\section{Visual detection of symptoms of viral infection}

The simplest way to detect a viral infection is to monitor physiological properties. Fever, dry cough, nasal congestion, runny nose, sore throat, myalgia, and fatigue are the main manifestations of respiratory (SARS-CoV-2 [142, 143], influenza viruses [144-146]). HIV destroys white blood cells (T-lymphocytes) in the human body. T-lymphocytes are responsible for controlling the body's immune system reactions. That means that after an HIV attack in the body, white blood cells can no longer control the body's immune system. The immune system gradually weakens, and the body can no longer defend itself against infections or diseases $[147,148]$. As the body weakens, rapid weight loss, muscle aches, joint pain, fever, general weakness, swollen lymph nodes, sore throat, diarrhea, 
night sweats, rash, drowsiness may occur [149-151]. Chickenpox $[152,153]$ is an acute viral disease characterized by fever, herpes on the skin and mucous membranes. These first symptoms appear 2 to 3 weeks after infection [154]. However, mention above symptoms can also be caused by different viruses or pathogens, so applying a visual method to make an accurate diagnosis is not appropriate. However, visual diagnosis of the viral disease is widely used to form a preliminary opinion or a starting point for further diagnosis.

\section{Molecular virus detection methods}

Molecular diagnostic methods are used to (i) detect antibodies to different viral proteins or (ii) to directly detect the whole virus or its components. The first molecular diagnostics methods became available in the 1970s when scientists began using recombinant DNA technology (constructed DNA probes) for virus detection [155, 156]. Recombinant DNA technologies: molecular cloning, nucleic acid hybridization, and the use of restriction enzymes to cut DNA at specific sites [157] are the most sensitive in vitro techniques for detecting small viral targets. However, those mentioned above molecular diagnostic methods did not apply to clinical virus diagnostics as the methods were based on radioisotopes (highly ${ }^{32}$ P-labeled nucleic acid probes). These methods were widely used only in virology research laboratories for virus investigation due to their sensitivity.

Detection of viral infection by serological (blood) tests allows the detection of virus type, subtype, viral load (by measuring viral RNA or DNA in the blood), drug resistance, and how long the organism has been infected with the pathogen. Moreover, blood samples can be stored for long periods and remain relatively stable. Plasma or serum is usually stored refrigerated or frozen for longterm storage, and dried blood stains remain stable at room temperature. Many viruses are excreted in large amounts in urine or saliva, so non-invasive samples [158] are also used to detect viruses using molecular virus detection methods. However, the purification of nucleic acid from a sample is the most important step in a molecular method in virology. High-quality nucleic acid is required for most molecular method applications, but they are essential for nucleic acid amplification, antibodyantigen technique, and sequencing. The nucleic acid purification step removes any inhibitors from the sample and concentrating the amount of nucleic acid. Inhibition of PCR and other molecular detection methods by nucleic acid extracts is a well-known phenomenon and has been widely described in several reports. Research has shown that urine $[159,160]$, phenolic groups (e.g., humic acids) [161, 162], complex polysaccharides (e.g., feces, plant material) [163, 164], collagen (e.g. tissues) [165], heme (e.g., blood) [166-168], humic acid (e.g., soil, plant material) [169-172], melanin and eumelanin (e.g., hair, skin) [173, 174], proteinases (e.g. milk) [175, 176], calcium ions (e.g., milk, bone) $[173,177]$ adversely negatively affects the test results obtained by molecular detection methods.

\section{Nucleic acid amplification methods for the diagnosis of virus induced diseases}

Nucleic acid amplification procedures, including PCR, real-time PCR PCR [184], RT-PCR [185], nucleic acid sequence-based amplification (NASBA) [186], and loop-mediated isothermal amplification (LAMP) [187] developed for most respiratory viruses, and today these sensitive nucleic acid amplification methods put to use in a routine clinical or diagnostic laboratory for detection respiratory and other pathogens. Since the development of PCR in $1983[178,179]$ the method was quickly adapted firstly for the detection of the human immunodeficiency virus (HIV) [180-182] and later for the diagnosis of respiratory and other viruses as well [183]. Nucleic acid amplification methods have high sensitivity and strong sequence specificity; the equipment and techniques are also validated [188-190].

Nucleic acid amplification is a straightforward technique for rapidly amplifying billions [191] of DNA copies of interest. PCR or real-time PCR involves effective [192-194] repetitive cyclic polymerization using thermostable DNA polymerase, excess amount of each of the four deoxyribonucleotide triphosphates, two oligonucleotide primers (short strands about $16-50$ bases of complementary nucleic acids), and target genetic material. In the first end-PCR point and real-time PCR stage of the cycle, the denaturation of the target doublestranded DNA is performed by heating (at over $90{ }^{\circ} \mathrm{C}$ ). In the next step, the two primers bind complementarily to two separate single-stranded DNAs $\left(\sim 40-50{ }^{\circ} \mathrm{C}\right)$, and at the third stage, the polymerization reaction is performed by DNA polymerase at $60-70{ }^{\circ} \mathrm{C}$. At the end of the first cycle, two double-stranded DNAs are produced from one double-stranded DNA [33, 184, 195-197]. The formula used to calculate the number of DNA copies generated after amplifying a given number of cycles is $2^{\mathrm{n}}$, where $\mathrm{n}$ is the number of cycles. Astonishing, using PCR or realtime PCR method, the 105-106 copies of DNR can be made in $25-30$ cycles within $\sim 2-3 \mathrm{~h}$. In RNA viruses, double-stranded DNA is prepared by cDNA technique using oligonucleotides and reverse transcriptase in the reaction. Real-time PCR is known to be more sensitive, faster, and much easier to perform when compared to conventional PCR by (reduced cycle time and steps, also there is no need for additional electrophoresis, staining, gel documentation, and risk of contamination is reduced. Detailed and comprehensive multiplex (possibilities of 
identifying multiple infectious agents) real-time RT-PCR study of RNA viruses was performed by Osman et al. The authors [198] used many different fruits and plants virus isolates. The results showed that multiple and single detections of real-time RT-PCR in other virus isolates are similar. The single- and two-stage multiplex real-time RT-PCR assays yielded comparable Cq values. This study has shown that multiple real-time RT-PCR testing simplifies virus detection. The process is partially automated. Due to selected conservative target sequences and RNase inhibitors in the reaction real-time RT-PCR specificity and sensitivity for RNA viruses are 99-100\% [199-205].

As mentioned earlier, the nucleic acid amplification technique requires generating and constructing one or two sequences directed to regions of the viral genes or viral structural proteins. Convenient that sequenced viral genomes are publicly available in databases. In molecular genetics, gene sequences contain open reading frames (ORFs) that encode regulatory (e.g., transcription) regions that can potentially be translated into proteins. An ORF is a continuous codon stretch with a start (usually AUG) codon and stops (usually UAA, UAG, UGA) codon [206]. The phylogenetic analysis of open-reading frames (ORFs) sequences identifies and designs highly conservative virus structure regions of interest.

Coronaviruses are large positive-chain enveloped single-stranded RNA viruses, and the $5^{\prime}$-terminal has two open reading frames (ORFs), $1 \mathrm{a}$ and $1 \mathrm{~b}$, and encodes two large polyproteins that are processed by viral proteases and involved in viral RNA synthesis [207-210]. The study by Udugama et al. showed that coronaviruses have three conserved sequence regions: the RdRP (RNA-dependent RNA polymerase) gene, the $\mathrm{E}$ (envelope protein) gene, and the $\mathrm{N}$ (nucleocapsid protein) gene [211]. The SARSCov-2 virus belongs to beta-Cov lineage B RNA viruses. It is characterized by apparent stick protrusion [212, 213] on the virus's surface and an abnormally large RNA genome [214]. SARS-Cov-2 virus genome encodes spike $(\mathrm{S})$ protein, matrix protein $(\mathrm{M})$ nucleocapsid $(\mathrm{N})$ protein, and envelope (E) proteins. However, the RdRP (3.6 copies/reaction) and E (3.9 copies/reaction) genes sequence have threefold higher analytical sensitivity than the $\mathrm{N}$ (>10 copies/reaction) gene [215-217] and are, therefore, highly recommended to use as targets for direct detection of coronaviruses. However, knowing the capabilities of PCR and real-time PCR technology, multiplex $\mathrm{PCR}$ can be used for three or more gene sequences in a single sample. Recently, multiplex RT-PCR studies have described the evaluation of different viruses and mutations [218-221].

HIV and other retroviruses are also RNA viruses and have three main open reading frames (ORFs). First, a gag or group-specific antigen is the major structural protein.
The second ORF is pol, encoding a polyprotein containing reverse transcriptase, integrase, and protease precursors. The third-env-encodes glycoproteins that are displayed on the virus's surface and cause viral recognition and fusion with the host cell [222]. Corti et al. confirm that the HIV gag and pol gene regions are excellent targets for direct virus detection. However, the env gene region is suitable as a target for antibody detection [223].

Influenza $\mathrm{A}, \mathrm{B}$, and $\mathrm{C}$ are negative-sense, singlestranded, segmented, and enveloped RNA (approximately $100 \mathrm{~nm}$ in diameter, $12,000-15,000$ nucleotides) viruses that belong to the orthomyxoviridae family. The influenza virus genome contains 7-8 single-stranded RNA gene segments (8 segments have influenza virus A and $B, 7$ parts-virus $C$ ) that encode ten different proteins. Matrix protein (MP), hemagglutinin (HA), neuraminidase (NA) proteins are present on the influenza virus surface and play essential roles in infecting a host cell. Hemagglutinin protein (HA) and neuraminidase protein (NA) are grouped into subtypes 16 and 9, and the sequences of these subtypes are very different even in subspecies, making them an effective means of monitoring viral changes. The influenza virus is unique due to mutations that lead to changes in two external proteins, HA and NA. Currently, antibodies to the NP gene are the sequence of the target molecule to detect influenza. Hemagglutinin (HA) gene and neuraminidase (NA) gene sequences are the most critical antigenic sites for producing a protective immune response. Matrix protein (MP) genes for influenza A and B viruses, hemagglutinin (HA) gene sequences for influenza $C$ virus were used as targets for PCR primers as well as other nucleic acid amplification methods in 1991 [224]. A comparative study has also been performed on the PCR system by varying the length of the forward and reverse primers (21 and 32 nucleotides in length) and the calcium chloride (10$200 \mathrm{mM}$ ) concentration [225]. The authors declare that the reaction's $90 \mathrm{mM}$ of calcium chloride is $10-100$ times more sensitive than the proposed antigen immunoassay system.

By Starick et al., the influenza A virus RNA was purified/prepared by the acid guanidine-thiocyanate method [226], hemagglutinin (HA) part selected nucleotide sequence for RT-PCR [227]. The authors didn't detail the concentration of viral RNA used. DNA fragments were evaluated after the PCR reaction visually in agarose gel. PCR products from selected isolates with known sequences were sequenced after cloning to confirm that accurate amplification was achieved. Paramyxoviruses of serotypes were used as controls to ensure the specificity of the studies. Hence, PCR methods have demonstrated no false-positive results. For further investigations by other authors $[29,228,229]$ the same RNA purified 
samples were chosen and more conserved gene sequence (matrix protein (MP)) as target primer for PCR reaction for direct virus detection. After electrophoresis, agarose gel visually assessed the PCR product (212 bp for influenza A virus, 365 bp for influenza B virus). The results of these studies clearly showed high sensitivity and suitability for virus detection in a PCR reaction.

Spackman et al. were developed a real-time RT-PCR assay based on matrix protein (MP) gene sequence as target primer [230]. The authors declare that the detection limit of the matrix gene real-time RT-PCR assay is $10 \mathrm{fg}$ or approximately 1000 copies of the target RNA. The matrix protein (MP), hemagglutinin $(\mathrm{H})$, and neuraminidase $(\mathrm{N})$ gene sequences, and the TaqMan probe with different FAM, VIC, and NED fluorescent signals have been experienced for single-step real-time RT-PCR assay by Payungporn et al. [231]. Payungporn et al., Panning et al. studies of a wide range of influenza A viruses have shown that the MA and HA gene sequences are equally susceptible to virus detection and are both suitable for real-time PCR [232]. The limit of detection with FAM fluorescent signals reached 384 RNA copies/ml. Multiplex [233] realtime RT-PCR analyses are increasingly used in clinical in vitro diagnostics to detect seasonal influenza viruses. Although PCR shows excellent sensitivity [234], it has several drawbacks: expensive reagents and devices, complicated operation, and reverse transcription for RNA detection.

Loop-mediated isothermal amplification method (LAMP) [235] - for DNR amplification at single incubation temperature using a set of four (two inners and two outer) unique primers to recognizing eight distinct sites of the target sequence. A DNA-displacing DNA polymerase (Bst or phi29 DNA polymerase) is used to initiate the synthesis, and the two primers form loop structures to facilitate and accelerate further amplification steps. RT-LAMP has been used for rapid and straightforward detection of RNA (10 copies/reaction) viruses [236]. The test results are analyzed with the naked eye due to the fluorescent dyes present in the system. Tracking results in real-time is also possible. Numerous [215, 237-240] studies have demonstrated the successful use of various LAMP tests to detect coronavirus RNA in serological samples. However, the LAMP method has a drawbackthe complexity of the methodology. The method requires the ability to design complex primers, and the method's resolution, accuracy, or specificity depend on this step.

NASBA-self-sustained and repetitive sequence replication and transcription reactions are very similar to PCR or real-time PCR techniques because of oligonucleotide primers. A multilevel and complex isothermal method is suitable for detecting RNA viruses: HIV [241243], coronaviruses [244, 245]. Several modification enzymes (AMV reverse transcriptase, ribonuclease $\mathrm{H}$, and T7 RNA polymerases) and their activities combine to produce many copies of double-stranded DNA and new RNA targets for further application. The method can make 107 copies of nucleic acid targets within $2.5 \mathrm{~h}$ [246, 247]. However, the technique is challenging. The oligonucleotide sequence must be complementary to the target virus RNA and the T7 RNA polymerase promoter sequence; otherwise, the amplification reaction will stop. The T7 RNA polymerase can amplify up to 50-1000 new RNA copies by transcription from one copy of RNA. Since this is a spontaneous and continuous process, the reaction ends when all the components are agitated, and equilibrium is reached without any thermocycling at constant $41{ }^{\circ} \mathrm{C}$ temperature. Of course, the fluorescent label can monitor amplification in real-time and obtain rapid test results [241]. The advantages of this method are two. The final reaction products are both dsDNA and RNA. DNA is the most often chosen for further application because it is more stable to various environmental conditions. However, the method's reliability for the detection of HIV in the gag and pol regions of the genome [248$250]$ is $93-98 \%$.

All the nucleic acid amplification methods listed here are widely used for detecting different viruses in samples. However, they are also commonly used in the application by combining other regions of the genome sequences to see individual virus prototypes [251] to increase the sensitivity and accuracy of the method.

A slight improvement in RT-PCR allowed the discovery of the Abbott ID Now COVID-19 method. The Abbott ID Now molecular point-of-care COVID-19 detection test is associated with high sensitivity and specificity, providing reliable positive results in $5-13 \mathrm{~min}$ [252, 253]. Abbott ID Now, the technique is based on isothermal nucleic acid amplification by using primers to allow specific amplification of RdRp viral target with a claimed LOD of 125 copies/mL [254]. Evaluation of the Abbott ID Now method has shown that the study performs well on strong and moderately positive samples but dramatically reduces the sensitivity to weakly positive models, confirming the findings of other published studies [255]. Therefore, Abbott ID Now has not been FDA cleared or approved.

\section{Antibody-antigen complex detection-based methods for the determination of virus induced diseases}

Conventional virologic methods are well known established [256]. The culture of the virus with immunohistological confirmation of viral antigen has long been the standard virus detection method. Many cell culture species exist for influenza viruses, such as human adenoid primary epithelial cells, Vero cells, MRC-5, Madin-Darby 
canine kidney (MDCK) cell line, and primary monkey kidney cells [257]. In clinical or diagnostic laboratories, after 2-10 days, the viral culture is performed by immunological methods, such as a direct immunofluorescence method or molecular biologic methods [258].

The hemagglutination inhibition (HAI) [259] method titrate the antibody response to a viral infection. The HAI assay is based on the virus's ability to hemagglutinate (bind) red blood cells, forming a 'lattice' and preventing red blood cells from clumping. However, the greatest stringency of the method is sensitive to some inhibitors, and in addition, not all viruses have the ability to hemagglutinate in interaction with antibodies. Rubella [260], avian influenza [261], influenza A and B [262, 263], swine [264], and other viruses have the properties listed above.

Directing is an enzyme-linked immunoassay (EIA) membrane method performed in a solid membrane based on an enzymatic reaction between enzyme-conjugated monoclonal antibodies specific towards virus proteins. Then the captured virus antigen-antibody pair is visualized by an enzymatic color development reaction $[265,266]$. The publications on EIA state that the method has high sensitivity, high specificity (nucleoproteins are used as antigens), rapid diagnosis (analysis last less than $15 \mathrm{~min}$ ), and technical simplicity. This method is applied prospectively directly, qualitatively, simultaneously for the detection of $\mathrm{A}$ and $\mathrm{B}$ virus antigens at the same time in different clinical samples of symptomatic patients [267]. However, comparing the data between the results of the cell culture method (shell vial) and the EIA method showed that the overall sensitivity of the EIA method is only $68.9 \%$. Hence, the EIA is one of the traditional methods for detecting type A and B influenza viruses in clinical diagnosis.

In the case of COVID-19 after 14 days [268], direct SARS-Cov 2 virus detection from the respiratory tract is not available (false-negative results), but antibody detection is possible and recommended. Recent preliminary studies have shown that both IgM and IgG increase with the SARS-Cov-2 infection phases and reach the highest level between two and three weeks [269, 270], even after a month of IgM traces are found [271]. Antibody studies focus on immunogenic coronavirus proteins: $S$ protein, most exposed to the viral protein, and $\mathrm{N}$ protein, which is abundantly expressed during infection [272]. Since respiratory disease is also a consequence of coronavirus, researchers determined IGA levels in patients with and without SARS-CoV-2. Although a strong IgA response was observed in patients with COVID-19, immunoglobulin peaked within two weeks. The IgA-based immunoassay [273] is less specific than the IgG-based ELISA due to the likelihood of samples infected with other coronaviruses.
In the case of HIV, another assay for virions, the enzyme-linked immunosorbent assay (ELISA) detecting HIV-1 gag, p24, has low sensitivity (103 to 106 virus particles $/ \mathrm{ml}$ ) and can also detect virus-like particles lacking genomic RNA and p24 released from dead cells [274-276].

For the semi-quantification of immunoglobulin G (IgG) antibodies in human serum, the lateral flow point-of-care techniques with specially designed recombinant viral proteins are increasingly started to use. The point-of-care system combines a biotinylated aptamer with a streptavidin test line and a secondary antibody control line. Rapid antibody tests are available, but the method cannot use them to monitor viral progression. Recent works with the Ebola virus [277], influenza virus [278, 279], HIV [280-282] have shown that the lateral flow pointof-care technique can achieve a significantly improved limit of detection and multiplex detection. The capsid protein (p24 antigen) and anti-HIV antibodies are the primary viral markers used to detect HIV infection in the lateral flow point-of-care system. The lateral flow pointof-care system was designed to detect amplified (142 bp) HIV RNA quantitatively. When RNA is distributed on a conjugate strip, the RNA binds to complementary oligonucleotides conjugated to gold nanoparticle probes. However, most studies suggest that in combination with nucleic acid amplification methods (NASBA, RPA, etc.), a lateral flow monitoring test can detect RNA concentrations of HIV or other viruses [280, 281, 283] But integrating lateral flow point-of-care analysis with amplification and sample preparation technologies complicates the application of the method in clinical diagnostics due to complexity.

Enzyme-linked immunosorbent assay (ELISA) [284] technique is used to quantify proteins, peptides, antibodies, or hormones in a biological system. The amount of antibodies in the blood reflects the body's overall ability to protect itself against infections and its ability to form an immune system. Antibody changes can occur in a variety of autoimmune diseases. In total, the human body produces five known classes of antibodies [285], labeled Ig (meaning immunoglobulins), which belong to A, M, G, E, and D classes. Thus, participants in the primary, acute infectious process are class $M$ immunoglobulins (IgM), showing a critical phase. Subsequently, IgM antibodies in the blood disappear, and class G immunoglobulins (IgG) production begins. In terms of $\mathrm{IgE}$, it is used to diagnose various parasitic invasions and allergic reactions, and IgD performs an ancillary function. ELISA is a sandwich method [286288 ] in which the antigen of a specific pathogen is layered on the surface, a biological substance is added (the patient's blood serum), and immune complex formation 
is formed. The assay is fixed with a unique chromogen component, and the color change is visually observed with fluorimeters. The relative disadvantage of ELISA is that the method only detects the immune responseantibodies but does not detect the pathogen itself.

Conservative sequences of the viral envelope genome are constructed for the ELISA method, which aims to detect antibodies to the virus formed in the body. Antibodies to the HIV envelope proteins gp 120 and $g p 160$ [289] are the most commonly detected in all saliva samples taken from HIV-positive individuals. Antibodies to other viral proteins $(p 65, p 51, g p 41, p 35, p 24, p 18)$ are detected in saliva at random without a clear correlation [290] with the clinical stage of the disease. Due to the growing global demand for rapid tests, attempts have been made to develop and evaluate an IgG-based ELISA for COVID-19 for detection. To determine the concentration of antibodies (anti-SARS-CoV-2), which belongs to the IgM and IgG class of proteins and these anti-SARS-CoV-2 antibodies selectively recognizing coronavirus spike $(\mathrm{S})$ and nucleocapsid $(\mathrm{N})$ proteins [291-293]. Studies show that in COVID-19, the positive IgG level is reaching $100 \%$ approximately 20 days after the onset of symptoms [294]. The mean seroconversion day for both IgG and IgM was 13 days after the onset of symptoms. IgM seroconversion occurred at the same time, earlier or later than IgG $[26,295,296]$. ELISA for COVID-19 detection was found to be $92.37 \%$ sensitive and $97.9 \%$ specific. The results show that the actual status of the infection and its spread can be determined using IgM and IgG antibodies against SARS-CoV-2 in serological tests such as ELISA. Furthermore, the ELISA method was developed and validated to detect anti-SARS-CoV-2 human IgG antibodies. Proposed ultraviolet colorimetric assay method-magnetic nanoenzyme linked immunosorbent assay (MagLISA). Here the [297-303] authors combined a silica shell with magnetic nanoparticles (MagNBs) and gold nanoparticles for influenza A virus $(0.02 \mathrm{pg} / \mathrm{ml})$ monitoring. The main concepts of the developed sensing platform for rapid and sensitive detection of influenza $A$ virus are two different probes capable of specifically recognizing the target virus. Anti-influenza virus antibody was immobilized on positively charged AuNPs via electrostatic attraction (fixation probe). Monodisperse $\mathrm{Fe}_{3} \mathrm{O}_{4}$ and nanocluster (FNC) modified with a silica coating were chosen as the capture probe to inhibit the activity of enzymes from the iron oxide surface (Mag). The fixation probe recognizes the target virus by a specific antigen-antibody interaction, after which the antibody-antigen structures are assembled while applying a magnetic field. Specific antigen-antibody or receptor-ligand interaction can be determined by various physicochemical methods ranging from micromechanical [304], gravimetric [305, 306], optical [307, 308], surface resonance [309-311], ellipsometric and electrochemical [312-314].

Electrochemical sensors sometimes are less sensitive in comparison to some other analytical signal detection methods mentioned above. However, they enable the determination of antibodies against some virus-proteins or vice versa-virus-proteins in somewhat turbid samples [312-314] so the method has not been commercialized yet. Diseases caused by viruses and other pathogens can be diagnosed using immunosensors. Fluorescence is a sensitive analytical signal determination method that is promising when low analyte concentrations are present in the aliquot [307, 308, 315]. However, in most photoluminescence-based ways, additional photoluminescence probes should be applied, which sometimes is a significant drawback because they need additional expensive chemicals such as antibodies conjugated with photoluminescence probe [314-316]. This drawback can be avoided when Surface Plasmon Resonance (SPR) based sensors [309-311, 317] and spectroscopic ellipsometry [318-325] based methods are applied. In addition, these sensors are less sophisticated in comparison with more sensitive optical methods. The most innovative electrochemical techniques, such as scanning electrochemical microscopy, also can be used for immunoanalytical purposes [312]. It should be noted that some resonance techniques (e.g., quartz crystal microbalances QCM and especially QCM with dissipation QCM-D) [305] and electromechanical resonators such as capacitive micromachined ultrasound transducers (CMUT) [304, 326] based method can be also well exploited in the development of immunosensors. Very promising are forms based on the application of molecularly imprinted polymers (MIPs), while virus proteins can be imprinted within some electrochemically deposited conducting polymers [34, 327]. Recent developments in protein imprinted MIP sensors are overviewed in other review papers [328]. For better validation or measurement results combination of very different analytical methods can be performed simultaneously [317].

\section{CRISPR-Cas system-based determination of viral infections} Specific High-sensitivity Enzymatic Reporter un-LOCKing (SHERLOCK) and DNA Endonuclease Targeted CRISPR Trans Reporter (DETECTR) are diagnostic tools that are based on the CRISPR-Cas system and can be used to detect specific RNA or DNA at low attomolar concentrations [329]. CRISPR (Clustered Regularly Interspaced Short Palindromic Repeats) is a natural tool for genome editing that is part of the prokaryotic immune system used to fight viruses and immunize the 
organism [330-335]. Cas (CRISPR-associated protein) in the CRISPR system is guided by RNA to target place, and Cas proteins are endonucleases or ribonucleases, an enzyme that cuts DNA or RNA [336-341]. Thus, the CRISPR-Cas complex acts as an antivirus system Cas protein programmed by guide RNA to cleave specific target viral DNA or RNA [336-340]. Over the past few years, researchers have realized that they can use the CRISPR-Cas system to cleave any DNA or RNA at the site of interest by replacing the guide RNA or Cas protein in the system $[342,343]$. The nucleases encoded by CRISPR-Cas can accurately recognize nucleic acid sequences. Therefore, their use in diagnostics for rapid testing is being investigated worldwide. The methods developed are sensittive, capable of rapid detection, do not require expensive equipment or training, and can be performed point-of-care.

Gootenberg et al. 2018 developed a method for a multiplexed and portable nucleic acid detection platform [343-345]. SHERLOCK technique is a detection method that combines isothermal amplification with a CRISPR Cas13 cleavage system. Although either Cas 12 or Cas13 enzyme [346-349] can be used for nucleic acid detection, SHERLOCK protocol focuses on Cas13 because it shows the highest sensitivity in the application. The technique requires introducing the T7 RNA polymerase promoter during pre-amplification and T7 RNA polymerase during the detection reaction to generate RNA and for Cas13 trans- cleavage activation. Cas13a protein guided by RNA binds and cleaves target RNA. SHERLOCK has become an excellent tool for detecting RNA viruses due to nonspecific cleavage [350,351]. This method has advantages such as no additional cDNA step is required, the short nucleotide sequence fused to a fluorescent reporter, and the quencher as point readings or in real-time with a plate reader or other compatible fluorimeter. The system is rather complex, and the construction of primers must be complementary for the virus and the enzyme sequences used in the system. However, the method requires several additional amplification steps, making it difficult to use the CRISPR-Cas technique in clinical diagnostics.

To detect the SARS-CoV-2 virus, the guide RNA is constructing according to the conservative sequence of the neuraminidase $(\mathrm{N})$ gene, spike (S) gene, and replicase polyprotein $1 \mathrm{ab}$ (Orf1ab) gene $[352,353]$ under both lateral-flow strip and fluorescence readouts according to varying nucleotide lengths (7-40 bp). It has been observed that low sensitivity using $\mathrm{N}$ genes is probably due to the longer ( $>28 \mathrm{bp}$ ) generated N RPA amplicon $[354,355]$. If, by extending the response time of the $\mathrm{N}$ gene RPA to $1 \mathrm{~h}$, the sensitivity of detection increases and corresponds to the sensitivity of the $S$ gene. Using lateral-flow protocols $10^{4}-10^{5}$ copies $/ \mathrm{ml}[28,356]$ sensitivity is achieved. Alternative amplification methods have shown that the $\mathrm{N}$ gene has a higher copy number than other segments of the SARS-CoV-2 genome, which helps to increase the sensitivity of detection. With the SHERLOCK platform, 1 copy/ul of Zika virus (ZIKV) and dengue virus (DENV) can be detected directly from patient samples (e.g., serum, urine, and saliva) within $2 \mathrm{~h}$ [357] and have successfully used the system for the detection of human viruses.

Chen et al. reported [358] the DETECTR (DNA endonuclease directed CRISPR trans reporter) method based on the CRISPR system and provides a straightforward platform for molecular diagnostics. DETECTR, like SHERLOCK, also achieves atomic sensitivity [347, 359]. DNA is detected by combining activation of Cas12a or Cas14a single strand DNase nonspecific single strand deoxyribonuclease with isothermal amplification, which allows rapid and specific virus detection from patient samples. Cas12a-DETECTR [360, 361] platform guided by RNA detect and cut target double-strand DNA by cis cleavage, also have the additional ability for trans- singlestranded DNA cleavage. Cas14a-DETECTR [362] mechanism guided by RNA binds and cut single-strand DNA. However, additional steps are required: cDNA (for RNA viruses) in the case of Cas12a protein, double-strand DNA conversion to single-strand DNA in case of Cas14a, and the nucleotides are designed according to the target RNA sequence and a short nucleotide sequence fused to a fluorescent reporter and quencher. Using lateral-flow protocols $10^{4}$ copies $/ \mathrm{ml}$ sensitivity is achieved. Primers targeting the SARS-CoV-2 genes $\mathrm{E}$ (envelope) and $\mathrm{N}$ (nucleoproteins) were designed [363] for the Cas12aDETECTR. SARS-CoV-2 virus RNA is purified from the patient sample, followed by reverse transcription and isothermal amplification using loop-induced amplification (RT-LAMP) to generate cDNA [27]. Detection of nucleic acid is performed under both lateral-flow strip and fluorescence reading conditions. Comparison of SARS-CoV-2 DETECTR lateral-flow strip with realtime RT-PCR methods showed $95 \%$ and $100 \%$ accuracy, respectively [27].

\section{Conclusions}

Nucleic acid amplification assays are described as a 'Gold Standard' method because of the general-purpose reagents manufactured and approved according to International Organization for Standardization (ISO) normative compliance and quality assurance (QA) rules for the accuracy of the method. Therefore, the regulatory framework and the validity of the technique ensures the reproducibility of the results, and the method is still widely used in the study, research, investigation, and detection of viruses and 
other pathogens. However, the new generation analytical method based on the nonspecific DNA cleavage observed in CRISPR-Cas type II (Cas9), V (Cas12 and Cas14), and VI (Cas13) systems provide promising advances in CRISPR-based diagnostics of emerging infectious diseases. Already developed and commercialized SHERLOCK and DETECTR methods are straightforward to apply for the detection of new pathogens. However, separate parts of the diagnostic procedure (nucleic acid amplification and detection, signal detection) as in nucleic acid amplification assays are necessary, and a more significant signal is obtained by more straightforward extraction of RNA from body fluid directly. These two advanced methods are based on thorough validations and field tests of diagnostic techniques to guarantee their functionality and ensure that virus or other pathogens detection is susceptible, high quality, specific, and well-functioning. Besides, the sensitivity and accuracy of the methods depend only on the chosen virus ORF gene sequence region. Hence it is worth picking several specific sequences in ORF-region for multiplex assay to quickly and accurately diagnose viral infection. However, the diagnosis of viral infections still faces many obstacles. Therefore, the knowledge and clarity about the methods will facilitate progress in this area.

\section{Acknowledgements}

Schematic illustrations and images were created using BioRender.com.

\section{Authors' contributions}

$J D, U S B$, and AR contributed equally to the review of literature, organization, and writing of this review article. All authors read and approved the final manuscript.

\section{Funding}

Regional Development Fund (project No 01.2.2-LMT-K-718-01-0063) under a Grant agreement with the Research Council of Lithuania (LMTLT).

\section{Availability of data and materials}

Not applicable.

\section{Declarations}

Ethics approval and consent to participate

Not applicable.

\section{Consent for publication}

Not applicable.

\section{Competing interests}

The authors declare that they have no competing interests.

\begin{abstract}
Author details
'Laboratory of Nanotechnology, Department of Functional Materials and Electronics, Center for Physical Sciences and Technology, Sauletekio av. 3, Vilnius, Lithuania. ${ }^{2}$ Department of Physical Chemistry, Faculty of Chemistry and Geoscience, Vilnius University, Naugarduko str. 24, 03225 Vilnius, Lithuania.
\end{abstract}

Received: 24 July 2021 Accepted: 11 October 2021

Published online: 30 October 2021
References

1. Rojek A, Horby P, Dunning J. Insights from clinical research completed during the west Africa Ebola virus disease epidemic. Lancet Infect Dis. 2017; 17:e280-92.

2. Valleron AJ, Meurisse S, Boelle PY. Historical Analysis of the 1889-1890 Pandemic in Europe. Int J Infect Dis. 2008;12:e95.

3. Kempińska BM, Woźniak AK. The influenza epidemic of 1889-90 in selected European cities - a picture based on the reports of two Poznań daily newspapers from the second half of the nineteenth century. Med Sci Monit. 2013;19:1131-41.

4. Trilla A, Trilla G, Daer C. The 1918 "Spanish Flu" in Spain. Clin Infect Dis. 2008. https://doi.org/10.1086/590567.

5. Guan Y, Vijaykrishna D, Bahl J, Zhu H, Wang J, Smith GJD. Minireview. The emergence of pandemic influenza viruses. Protein Cell. 2010;1:9-13.

6. Cohen MS, Hellmann N, Levy JA, Decock K, Lange J. The spread, treatment, and prevention of HIV-1: evolution of a global pandemic. J Clin Investig. 2008;118:1244-54.

7. Cucinotta D, Vanelli M. WHO declares COVID-19 a pandemic. Acta Biomed. 2020;91:157-60. https://doi.org/10.7326/M20-0504.

8. Halkitis PN. Managing the COVID-19 pandemic: biopsychosocial lessons gleaned from the AIDS epidemic. J Public Health Manag Pract. 2021;27:S39-42. https://doi.org/10.1097/PHH.0000000000001267.

9. Velavan TP, Meyer CG. The COVID-19 epidemic. Trop Med Int Health. 2020;25:278-80.

10. Gorbalenya AE, Baker SC, Baric RS, de Groot RJ, Drosten C, Gulyaeva AA, et al. The species Severe acute respiratory syndrome-related coronavirus: classifying 2019-nCoV and naming it SARS-CoV-2. Nat Microbiol. 2020. https://doi.org/10.1038/s41564-020-0695-z.

11. Taubenberger JK, Morens DM, Fauci AS. The next influenza pandemic: can it be predicted? J Am Med Assoc. 2007;297:2025-7.

12. Valleron AJ, Cori A, Valtat S, Meurisse S, Carrat F, Boëlle PY. Transmissibility and geographic spread of the 1889 influenza pandemic. Proc Natl Acad Sci USA. 2010;107:8778-81.

13. Vijgen L, Keyaerts E, Moës E, Thoelen I, Wollants E, Lemey P, et al. Complete genomic sequence of human coronavirus OC43: molecular clock analysis suggests a relatively recent zoonotic coronavirus transmission event. J Virol. 2005;79:1595-604.

14. Mulder J, Masurel N. Pre-epidemic antibody against 1957, strain of Asiatic influenza in serum of older people living in the Netherlands. Lancet. 1958;1:810-4.

15. Noor R, Maniha SM. A brief outline of respiratory viral disease outbreaks: 1889-till date on the public health perspectives. Virusdisease. 2020;31:441-9. https://doi.org/10.1007/s13337-020-00628-5.

16. Ryan JR. Pandemic influenza: emergency planning and community preparedness. 2008.

17. Oxford JS, Lambkin R, Sefton A, Daniels R, Elliot A, Brown R, et al. A hypothesis: The conjunction of soldiers, gas, pigs, ducks, geese and horses in Northern France during the Great War provided the conditions for the emergence of the "Spanish" influenza pandemic of 1918-1919. Vaccine. 2005;23:940-5.

18. Barry JM. The site of origin of the 1918 influenza pandemic and its public health implications. J Transl Med. 2004. https://doi.org/10.1186/ 1479-5876-2-3.

19. Worobey M, Cox J, Gill D. The origins of the great pandemic. Evol Med Public Health. 2019;2019:18-25.

20. Wertheim JO. The re-emergence of H1N1 influenza virus in 1977: a cautionary tale for estimating divergence times using biologically unrealistic sampling dates. PLOS ONE. 2010;5:e11184. https://doi.org/10. 1371/journal.pone.0011184.

21. Taubenberger JK. The origin and virulence of the 1918 "Spanish" influenza virus. Proc Am Philos Soc. 2006;150:86-112.

22. Bosch A, Sánchez G, Abbaszadegan M, Carducci A, Guix S, le Guyader FS, et al. Analytical methods for virus detection in water and food. Food Anal Methods. 2011;4:4-12. https://doi.org/10.1007/s12161-010-9161-5.

23. Mahapatra S, Chandra P. Clinically practiced and commercially viable nanobio engineered analytical methods for COVID-19 diagnosis. Biosens Bioelectron. 2020;165:112361.

24. Hui DS, Azhar El, Madani TA, Ntoumi F, Kock R, Dar O, et al. The continuing 2019-nCoV epidemic threat of novel coronaviruses to global 
health - the latest 2019 novel coronavirus outbreak in Wuhan, China. Int J Infect Dis. 2020;91:264-6.

25. Sheridan C. Fast, portable tests come online to curb coronavirus pandemic. Nat Biotechnol. 2020;38:515-8.

26. van Elslande J, Houben E, Depypere M, Brackenier A, Desmet S, André $E$, et al. Diagnostic performance of seven rapid lgG/lgM antibody tests and the Euroimmun IgA/lgG ELISA in COVID-19 patients. Clin Microbiol Infect. 2020;26:1082-7.

27. Broughton JP, Deng X, Yu G, Fasching CL, Servellita V, Singh J, et al. CRISPR-Cas12-based detection of SARS-CoV-2. Nat Biotechnol. 2020;38:870-4. https://doi.org/10.1038/s41587-020-0513-4.

28. Wang $X$, Shang $X$, Huang $X$. Next-generation pathogen diagnosis with CRISPR/ Cas-based detection methods Next-generation pathogen diagnosis with CRISPR/Cas-based detection methods. Emerg Microb Infect. 2020. https://doi.org/10.1080/22221751.2020.1793689.

29. Steininger C, Kundi M, Aberle SW, Aberle JH, Popow-Kraupp T. Effectiveness of reverse transcription-PCR, virus isolation, and enzyme-linked immunosorbent assay for diagnosis of influenza A virus infection in different age groups. J Clin Microbiol. 2002;40:2051-6.

30. Dawson WO, Beck DL, Knorr DA, Grantham GL. cDNA cloning of the complete genome of tobacco mosaic virus and production of infectious transcripts. Proc Natl Acad Sci USA. 1986:83:1832-6.

31. Khan MZH, Hasan MR, Hossain SI, Ahommed MS, Daizy M. Ultrasensitive detection of pathogenic viruses with electrochemical biosensor: state of the art. Biosens Bioelectron. 2020;166:112431.

32. Ramanaviciene A, Ramanavicius A. Pulsed amperometric detection of DNA with an ssDNA/polypyrrole-modified electrode. Anal Bioanal Chem. 2004;379:287-93. https://doi.org/10.1007/s00216-004-2573-6.

33. Dronina J, Bubniene US, Ramanavicius A. The application of DNA polymerases and Cas9 as representative of DNA-modifying enzymes group in DNA sensor design (review). Biosen Bioelectron. 2020;175:112867.

34. Ratautaite V, Topkaya SN, Mikoliunaite L, Ozsoz M, Oztekin Y, Ramanaviciene $\mathrm{A}$, et al. Molecularly imprinted polypyrrole for DNA determination. Electroanalysis. 2013;25:1169-77. https://doi.org/10.1002/elan. 201300063.

35. Threats I of M (US) F on M. Detection and Diagnostics. National Academies Press (US); 2007.

36. Long C, Xu H, Shen Q, Zhang X, Fan B, Wang C, et al. Diagnosis of the Coronavirus disease (COVID-19): rRT-PCR or CT? Eur J Radiol. 2020;126:108961.

37. Brunese L, Mercaldo F, Reginelli A, Santone A. Explainable deep learning for pulmonary disease and Coronavirus COVID-19 detection from X-rays. Comput Methods Programs Biomed. 2020;196:105608.

38. Fang $Y$, Zhang $H$, Xie J, Lin $M$, Ying $L$, Pang $P$, et al. Sensitivity of chest CT for COVID-19: comparison to RT-PCR. Radiology. 2020;296:E115-7. https://doi.org/10.1148/radiol.2020200432.

39. Shimizu YK, Feinstone SM, Kohara M, Purcell RH, Yoshikura H. Hepatitis C virus: Detection of intracellular virus particles by electron microscop. Hepatology. 1996;23:205-9. https://doi.org/10.1002/hep.510230202.

40. Ben-Shmuel A, Brosh-Nissimov T, Glinert I, Bar-David E, Sittner A, Poni $R$, et al. Detection and infectivity potential of severe acute respiratory syndrome coronavirus 2 (SARS-CoV-2) environmental contamination in isolation units and quarantine facilities. Clin Microbiol Infect. 2020;26:1658-62

41. van Doremalen N, Bushmaker T, Morris DH, Holbrook MG, Gamble A Williamson BN, et al. Aerosol and surface stability of SARS-CoV-2 as compared with SARS-CoV-1. N Engl J Med. 2020;382:1564-7. https:// doi.org/10.1056/nejmc2004973.

42. Murphy FA. Epidemiology of viral diseases. Encycl Virol. 1999; p. 482-7.

43. Tahamtan A, Ardebili A. Real-time RT-PCR in COVID-19 detection: issues affecting the results. Expert Rev Mol Diag. 2020;20:453-4.

44. Kim JY, Ko J-H, Kim Y, Kim Y-J, Kim J-M, Chung Y-S, et al. Viral load kinetics of SARS-CoV-2 infection in first two patients in Korea. J Korean Med Sci. 2020. https://doi.org/10.3346/jkms.2020.35.e86.

45. Wang Y, Kang H, Liu X, Tong Z. Combination of RT-qPCR testing and clinical features for diagnosis of COVID-19 facilitates management of SARS-CoV-2 outbreak. J Med Virol. 2020;92:538-9. https://doi.org/10. 1002/jmv.25721.

46. Meo SA, Alhowikan AM, Khlaiwi TAL, Meo IM, Halepoto DM, Iqbal M, et al. Novel coronavirus 2019-nCoV: prevalence, biological and clinical characteristics comparison with SARS-CoV and MERS-CoV. Eur Rev Med Pharmacol Sci. 2020;24:2012-9.

47. Cucinotta D, Vanelli M. WHO declares COVID-19 a pandemic. Acta Biomedica. 1885;2020(91):157-60.

48. Lei S, Jiang F, Su W, Chen C, Chen J, Mei W, et al. Clinical characteristics and outcomes of patients undergoing surgeries during the incubation period of COVID-19 infection. EClinicalMedicine. 2020;21:100331.

49. Lauer SA, Grantz KH, Bi Q, Jones FK, Zheng Q, Meredith HR, et al. The incubation period of coronavirus disease 2019 (CoVID-19) from publicly reported confirmed cases: estimation and application. Ann Int Med. 2020;172:577-82. https://doi.org/10.7326/M20-0504.

50. Gao Y, Shi C, Chen Y, Shi P, Liu J, Xiao Y, et al. A cluster of the Corona Virus Disease 2019 caused by incubation period transmission in Wuxi, China. J Infect. 2020;80:666-70

51. Gussow AB, Auslander N, Wolf YI, Koonin E. Prediction of the incubation period for COVID-19 and future virus disease outbreaks. BMC Biol. 2020;18:1-12. https://doi.org/10.1186/s12915-020-00919-9.

52. Bara J, Rapti Z, Cáceres CE, Muturi EJ. Effect of larval competition on extrinsic incubation period and vectorial capacity of Aedes albopictus for dengue virus. PLoS ONE. 2015;10:e0126703. https://doi.org/10.1371/ journal.pone. 0126703 .

53. Nishiura H, Halstead SB. Natural history of dengue virus (DENV)-1 and DENV-4 infections: reanalysis of classic studies. J Infect Dis. 2007:195:1007-13. https://doi.org/10.1086/511825.

54. Tjaden NB, Thomas SM, Fischer D, Beierkuhnlein C. Extrinsic Incubation period of dengue: knowledge, backlog, and applications of temperature dependence. PLoS Negl Trop Dis. 2013;7:e2207. https://doi.org/10. 1371/journal.pntd.0002207.

55. Chan M, Johansson MA. The incubation periods of dengue viruses. PLoS ONE. 2012;7:e50972. https://doi.org/10.1371/journal.pone.0050972.

56. Krow-Lucal ER, Biggerstaff BJ, Staples JE. Estimated incubation period for zika virus disease. Emerg Infect Dis. 2017;23:841-4.

57. Lessler J, Ott CT, Carcelen AC, Konikoff JM, Williamson J, Bi Q, et al. Times to key events in Zika virus infection and implications for blood donation: a systematic review. Bull World Health Org. 2016;94:841-9.

58. Fourié T, Grard G, Leparc-Goffart I, Briolant S, Fontaine A. Variability of Zika Virus incubation period in humans. Open Forum Infect Dis. 2018. https://doi.org/10.1093/ofid/ofy261/5128777.

59. Aziz H, Zia A, Anwer A, Aziz M, Fatima S, Faheem M. Zika virus: global health challenge, threat and current situation. J Med Virol. 2017;89:94351. https://doi.org/10.1002/jmv.24731.

60. Eichner M, Dowell SF, Firese N. Incubation period of ebola hemorrhagic virus subtype Zaire. Osong Public Health Res Perspect. 2011;2:3-7.

61. Haas CN. On the quarantine period for ebola virus. PLoS Curr. 2014;6. pmc/articles/PMC4205154/?report=abstract

62. Dixon MG, Schafer IJ. Ebola viral disease outbreak—West Africa, 2014. Ann Emerg Med. 2015; p. 114-5. http://who.int/csr/

63. Kadanali A. An overview of Ebola virus disease. North Clin Istanbul. 2016:2:81.

64. Koff RS. Clinical manifestations and diagnosis of hepatitis A virus infection. Vaccine. 1992;10:S15-7.

65. Prince AM. An antigen detected in the blood during the incubation period of serum hepatitis. Proc Natl Acad Sci USA. 1968:60:814-21.

66. Chang MH. Hepatitis B virus infection. Semin Fetal Neonatal Med. 2007:12:160-7.

67. Mahoney FJ. Update on diagnosis, management, and prevention of hepatitis B virus infection. Clin Microbiol Rev. 1999;12:351-66.

68. Liang TJ. Hepatitis B: The virus and disease. Hepatology. 2009;49:S13-21. https://doi.org/10.1002/hep.22881.

69. Juszczyk J. Clinical course and consequences of hepatitis B infection. Vaccine. 2000;18:523-5.

70. Villeneuve JP. The natural history of chronic hepatitis B virus infection. J Clin Virol. 2005;34:S139-42.

71. Vos LM, Bruning AHL, Reitsma JB, Schuurman R, Riezebos-Brilman A Hoepelman AIM, et al. Rapid molecular tests for influenza, respiratory syncytial virus, and other respiratory viruses: a systematic review of diagnostic accuracy and clinical impact studies. Clin Infect Dis. 2019;69:1243-53.

72. Ivanowski D. Ueber die mosaikkrankheit der tabakspflanze. St Petersb Acad Imp Sci Bul. 1892;35:67-70. 
73. Mayer A. Über die Mosaikkrankheit des Tabaks. Die Landwirtschaftliche Versuchs-stationen. 1886;32:451-67.

74. Harrison BD, Wilson TMA. Milestones in the research on tobacco mosaic virus. Royal Soc. 1999;354:521-9.

75. Lecoq H. Découverte du premier virus, le virus de la mosaïque du tabac: 1892 ou 1898 ? Comptes Rendus de l'Académie des Sciences Series III - Sciences de la Vie. 2001;324:929-33.

76. Creager ANH, Scholthof KBG, Citovsky V, Scholthof HB. Tobacco mosaic virus: pioneering research for a century. Plant Cell. 1999;11:301-8.

77. Ruska E. The development of the electron microscope and of electron microscopy(Nobel Lecture). Angewandte Chemie International Edition in English. 1987;26:595-605. https://doi.org/10.1002/anie.198705953.

78. Stanley WM. A crystalline protein with tobacco-mosaic virus properties. Science. 1935;81:644-5.

79. Rifkind D, Freeman GL. Tobacco mosaic virus. The nobel prize winning discoveries in infectious diseases. Amsterdam: Elsevier; 2005. p. 81-4.

80. Eriksson-Quensel IB, Svedberg T. Sedimentation and electrophoresis of the tobacco-mosaic virus protein. J Am Chem Soc. 1936;58:1863-7. https://doi.org/10.1021/ja01301a010.

81. Bawden FC, Pirie NW, Bernal JD, Fankuchen I. Liquid crystalline substances from virus-infected plants. Nature. 1936;138:1051-2.

82. Debrick KS. Quantitative assay for plant viruses using serologically specific electron microscopy. Virology. 1973;56:652-3.

83. Steere RL. Electron microscopy of structural detail in frozen biological specimens. J Biophys Biochem Cytol. 1957;3:45-60.

84. Namba K, Pattanayek R, Stubbs G. Visualization of protein-nucleic acid interactions in a virus. Refined structure of intact tobacco mosaic virus at $2.9 \AA$ A resolution by X-ray fiber diffraction. J Mol Biol. 1989;208:307-25.

85. Bloomer AC, Champness JN, Bricogne G, Staden R, Klug A. Protein disk of tobacco mosaic virus at $2.8 \AA$ resolution showing the interactions within and between subunits. Nature. 1978;276:362-8. https://doi.org/ 10.1038/276362a0.pdf.

86. Stubbs G, Warren S, Holmes K. Structure of RNA and RNA binding site in tobacco mosaic virus from 4-Å map calculated from X-ray fibre diagrams. Nature. 1977;267:216-21.

87. Franklin RE. Structure of tobacco mosaic virus. Nature. 1955;175:379-81. https://doi.org/10.1038/175379a0.pdf.

88. Tsugita A, Gish DT, Young J, Fraenkel-Conrat H, Knight CA, Stanley WM The complete amino acid sequence of the protein of tobacco mosaic virus. Proc Natl Acad Sci. 1960;46:1463-9.

89. Anderer FA, Uhlig H, Weber E, Schramm G. Primary structure of the protein of tobacco mosaic virus. Nature. 1960;186:922-5. https://doi. org/10.1038/186922a0.pdf.

90. Gallie DR, Sleat DE, Watts JW, Turner PC, Wilson T, Michael A. The 5 '-leader sequence of tobacco mosaic virus RNA enhances the expression of foreign gene transcripts in vitro and in vivo. Nucleic Acids Res. 1987;15:3257-73.

91. Golemboski DB, Lomonossoff GP, Zaitlin M. Plants transformed with a tobacco mosaic virus nonstructural gene sequence are resistant to the virus. Proc Natl Acad Sci USA. 1990;87:6311-5.

92. Goelet P, Lomonossoff GP, Butler PJG, Akam ME, Gait MJ, Karn J. Nucleotide sequence of tobacco mosaic virus RNA. Proc Natl Acad Sci USA. 1982:79:5818-22.

93. Zimmern $\mathrm{D}$. The nucleotide sequence at the origin for assembly on tobacco mosaic virus RNA. Cell Cell Press. 1977:11:463-82.

94. Powell PA, Stark DM, Sanders PR, Beachy RN. Protection against tobacco mosaic virus in transgenic plants that express tobacco mosaic virus antisense RNA. Proc Natl Acad Sci USA. 1989:86:6949-52.

95. Nelson RS, Abel PP, Beachy RN. Lesions and virus accumulation in inoculated transgenic tobacco plants expressing the coat protein gene of tobacco mosaic virus. Virology. 1987;158:126-32.

96. Ruiz JM, Ríos JJ, Rosales MA, Rivero RM, Romero L. Grafting between tobacco plants to enhance salinity tolerance. J Plant Physiol. 2006:163:1229-37.

97. Arce-Johnson P, Reimann-Philipp U, Padgett HS, Rivera-Bustamante R, Beachy RN. Requirement of the movement protein for long distance spread of tobacco mosaic virus in grafted plants. Mol Plant-Microbe Int. 1997;10:691-9. https://doi.org/10.1094/MPMI.1997.10.6.691.

98. Pallas JA, Paiva NL, Lamb C, Dixon RA. Tobacco plants epigenetically suppressed in phenylalanine ammonia-lyase expression do not develop systemic acquired resistance in response to infection by tobacco mosaic virus. Plant J. 1996;10:281-93. https://doi.org/10.1046/j. 1365-313X.1996.10020281.X.

99. Kathiria P, Sidler C, Golubov A, Kalischuk M, Kawchuk LM, Kovalchuk I. Tobacco mosaic virus infection results in an increase in recombination frequency and resistance to viral, bacterial, and fungal pathogens in the progeny of infected tobacco plants $1[\mathrm{C}][\mathrm{W}][\mathrm{OA}]$. Plant Physiol. 2010;153:1859-70. https://doi.org/10.1104/pp.110.157263.

100. Wisniewski LA, Powell PA, Nelson RS, Beachy RN. Local and systemic spread of tobacco mosaic virus in transgenic tobacco. Plant Cell. 1990;2:559-67.

101. Roingeard P. Viral detection by electron microscopy: past, present and future. Biol Cell. 2008;100:491-501. https://doi.org/10.1042/BC200 70173.

102. Barreto-Vieira DF, Barth OM. Negative and positive staining in transmission electron microscopy for virus diagnosis. Microbiol Agric Hum Health. 2015. https://doi.org/10.5772/60511.

103. Tyrrell DAJ, Almeida JD. Direct electron-microscopy of organ cultures for the detection and characterization of viruses. Archiv für die gesamte Virusforschung. 1967;22:417-25. https://doi.org/10.1007/BF01242962. pdf.

104. Hamm FA. Electron microscopy. Anal Chem. 1950;22:26-30. https://doi. org/10.1021/ac60037a010.

105. Swerdlow M, Dalton AJ, Birks LS. Electron microscopy. Anal Chem. 1956;28:597-609. https://doi.org/10.1021/ac60112a007.

106. Botty MC, Thomas AM. Electron microscopy. Anal Chem. 1962;34:127R-143R. https://doi.org/10.1021/ac60185a016.

107. Hazelton PR, Gelderblom HR. Electron microscopy for rapid diagnosis of infectious agents in emergent situations. Emerg Infect Dis. 2003;9(3):294

108. Reid GG, Milne EW, Coggins LW, Wilson NJ, Smith KT, Shepherd AJ. Comparison of electron microscopic techniques for enumeration of endogenous retrovirus in mouse and Chinese hamster cell lines used for production of biologics. J Virol Methods. 2003;108:91-6.

109. Malenovska H. Virus quantitation by transmission electron microscopy, TCID50, and the role of timing virus harvesting: a case study of three animal viruses. JVirol Methods. 2013;191:136-40.

110. Zhang $Y$, van der Schaar M. Reputation-based incentive protocols in crowdsourcing applications. Proceedings - IEEE INFOCOM. 2012. p. 2140-8.

111. Wilson IG. Inhibition and facilitation of nucleic acid amplification. Appl Environ Microbiol. 1997;63:3741-51.

112. Cliver DO, Yeatman J. Ultracentrifugation in the concentration and detection of enteroviruses. Appl Environ Microbiol. 1965;13:387-92.

113. Prata C, Ribeiro A, Cunha Â, Gomes NCM, Almeida A. Ultracentrifugation as a direct method to concentrate viruses in environmental waters: Virus-like particle enumeration as a new approach to determine the efficiency of recovery. J Environ Monit. 2012;14:64-70.

114. Victoria M, Guimarães F, Fumian T, Ferreira F, Vieira C, Leite JP, et al. Evaluation of an adsorption-elution method for detection of astrovirus and norovirus in environmental waters. J Virol Methods. 2009;156:73-6.

115. Fumian TM, Leite JPG, Castello AA, Gaggero A, de Caillou MSL, Miagostovich MP. Detection of rotavirus A in sewage samples using multiplex qPCR and an evaluation of the ultracentrifugation and adsorption-elution methods for virus concentration. J Virol Methods. 2010;170:42-6.

116. Hamza IA, Jurzik L, Stang A, Sure K, Überla K, Wilhelm M. Detection of human viruses in rivers of a densly-populated area in Germany using a virus adsorption elution method optimized for PCR analyses. Water Res. 2009:43:2657-68.

117. di Pasquale S, Paniconi M, Auricchio B, Orefice L, Schultz AC, de Medici D. Comparison of different concentration methods for the detection of hepatitis A virus and calicivirus from bottled natural mineral waters. J Virol Methods. 2010;165:57-63.

118. Bishop RF, Davidson GP, Holmes IH, Ruck BJ. Detection of a new virus by electron microscopy of fæcal extracts from children with acute gastroenteritis. Lancet. 1974;303:149-51.

119. Roingeard P, Raynal P-I, Eymieux S, Blanchard E. Virus detection by transmission electron microscopy: Still useful for diagnosis and a plus for biosafety. Rev Med Virol. 2019;29:e2019. https://doi.org/10.1002/rmv. 2019. 
120. Murray K, Selleck P, Hooper P, Hyatt A, Gould A, Gleeson L, et al. A morbillivirus that caused fatal disease in horses and humans. Science. 1995;268:94-7.

121. Ebrahim GJ. Swine Flu (S-OIV) Pandemic. J Trop Pediatr. 2010;56:1-3. https://doi.org/10.1093/tropej/fmp130.

122. Farndon J. Bird Flu: Everything you need to know. Red Wheel Weiser; 2006.

123. Ryabchikova El, Price BBS. Ebola and Marburg viruses: a view of infection using electron microscopy. Columbus: Battelle Press; 2004.

124. Facchetti F, Bugatti M, Drera E, Tripodo C, Sartori E, Cancila V, et al. SARS-CoV2 vertical transmission with adverse effects on the newborn revealed through integrated immunohistochemical, electron microscopy and molecular analyses of Placenta. EBioMedicine. 2020;59:102951.

125. Lučić V, Förster F, Baumeister W. Structural studies by electron tomography: from cells to molecules. Ann Rev Biochem. 2005;74:833-65. https://doi.org/10.1146/annurev.biochem.73.011303.074112.

126. Heider S, Metzner C. Quantitative real-time single particle analysis of virions. Virology. 2014;462:199-206.

127. Ohnesorge FM, Hörber JKH, Häberle W, Czerny CP, Smith DPE, Binnig G. AFM review study on pox viruses and living cells. Biophys J Biophys Soc. 1997;73:2183-94.

128. Wei Z, Mcevoy M, Razinkov V, Polozova A, Li E, Casas-Finet J, et al. Biophysical characterization of influenza virus subpopulations using field flow fractionation and multiangle light scattering: correlation of particle counts, size distribution and infectivity. J Virol Methods. 2007;144:122-32.

129. Bousse T, Shore DA, Goldsmith CS, Hossain MJ, Jang Y, Davis CT, et al. Quantitation of influenza virus using field flow fractionation and multi-angle light scattering for quantifying influenza A particles. J Virol Methods. 2013;193:589-96.

130. Anderson B, Rashid MH, Carter C, Pasternack G, Rajanna C, Revazishvili $T$, et al. Enumeration of bacteriophage particles. Bacteriophage. 2011;1:86-93. https://doi.org/10.4161/bact.1.2.15456.

131. Kramberger P, Ciringer M, Trancar A, Peterka M. Evaluation of nanoparticle tracking analysis for total virus particle determination. Virol J. 2012;9:1-10. https://doi.org/10.1186/1743-422X-9-265.

132. Papanikolaou E, Kontostathi G, Drakopoulou E, Georgomanoli M, Stamateris E, Vougas K, et al. Characterization and comparative performance of lentiviral vector preparations concentrated by either one-step ultrafiltration or ultracentrifugation. Virus Res. 2013;175:1-11.

133. Weidmann M, Sall AA, Manuguerra JC, Koivogui L, Adjami A, Traoré FF, et al. Quantitative analysis of particles, genomes and infectious particles in supernatants of haemorrhagic fever virus cell cultures. Virol J. 2011;8:81. https://doi.org/10.1186/1743-422X-8-81.

134. Chao W, Harteneck BD, Liddle JA, Anderson EH, Attwood DT. Soft $X$-ray microscopy at a spatial resolution better than $15 \mathrm{~nm}$. Nature. 2005;435:1210-3.

135. Chichón FJ, Rodríguez MJ, Pereiro E, Chiappi M, Perdiguero B, Guttmann P, et al. Cryo X-ray nano-tomography of vaccinia virus infected cells. J Struct Biol. 2012;177:202-11.

136. Kohno N, Ikezoe J, Johkoh T, Takeuchi N, Tomiyama N, Kido S, et al. Focal organizing pneumonia: CT appearance. Radiology. 1993;189:119-23. https://doi.org/10.1148/radiology.189.1.8372180.

137. Chung M, Bernheim A, Mei X, Zhang N, Huang M, Zeng X, et al. CT imaging features of 2019 novel coronavirus (2019-NCoV). Radiology. 2020;295:202-7. https://doi.org/10.1148/radiol.2020200230.

138. Deng L, Khan A, Zhou W, Dai Y, Eftekhar M, Chen R, et al. Follow-up study of clinical and chest CT scans in confirmed COVID-19 patients. Radiol Infect Dis. 2020;7:106-13.

139. Pautrat K, Chergui N. SARS-CoV-2 infection may result in appendicular syndrome: chest CT scan before appendectomy. J Visceral Surg. 2020;157:S63-4

140. Lubner MG, Jones D, Kloke J, Said A, Pickhardt PJ. CT texture analysis of the liver for assessing hepatic fibrosis in patients with hepatitis $C$ virus. Br J Radiol. 2018;92:20180153. https://doi.org/10.1259/bjr.20180153.

141. Ronot M, Asselah T, Paradis V, Michoux N, Dorvillius M, Baron G, et al. Liver fibrosis in chronic hepatitis C virus infection: Differentiating minimal from intermediate fibrosis with perfusion CT. Radiology. 2010;256:135-42. https://doi.org/10.1148/radiol.10091295.
142. Bender WR, Hirshberg A, Coutifaris P, Acker AL, Srinivas SK. Universal testing for severe acute respiratory syndrome coronavirus 2 in 2 Philadelphia hospitals: carrier prevalence and symptom development over 2 weeks. Am J Obstetr GynecolMFM. 2020;2:100226. https://doi. org/10.1016/j.ajogmf.2020.100226.

143. Pérez-García F, Pérez-Tanoira R, Romanyk J, Arroyo T, Gómez-Herruz $P$, Cuadros-González J. Alltest rapid lateral flow immunoassays is reliable in diagnosing SARS-CoV-2 infection from 14 days after symptom onset: a prospective single-center study. J Clin Virol. 2020;129:104473.

144. Moser MR, Bender TR, Margolis HS, Noble GR, Kendal AP, Ritter DG. AN outbreak of influenza aboard a commercial airliner. Am J Epidemiol. 1979:110:1-6.

145. Monto AS, Gravenstein S, Elliott M, Colopy M, Schweinle J. Clinical signs and symptoms predicting influenza infection. Arch Intern Med. 2000;160:3243-7

146. Ohmit SE, Monto AS. Symptomatic predictors of influenza virus positivity in children during the influenza season. Clin Infect Dis. 2006;43:564-8. https://doi.org/10.1086/506352.

147. Singer EJ, Zorilla C, Fahy-Chandon B, Chi S, Syndulko K, Tourtellotte WW. Painful symptoms reported by ambulatory HIV-infected men in a longitudinal study. Pain. 1993;54:15-9.

148. Brandt C, Zvolensky MJ, Woods SP, Gonzalez A, Safren SA, O'Cleirigh CM. Anxiety symptoms and disorders among adults living with HIV and AIDS: a critical review and integrative synthesis of the empirical literature. Clin Psychol Rev. 2017;51:164-84

149. Coleman CL. Spirituality, psychological well-being, and HIV symptoms for african americans living with HIV disease. J Assoc Nurses AIDS Care. 1999;10:42-50.

150. Belkin GS, Fleishman JA, Stein MD, Piette J, Mor V. Physical symptoms and depressive symptoms among individuals with HIV infection. Psychosomatics. 1992;33:416-27.

151. Burack JH, Barrett DC, Stall RD, Chesney MA, Ekstrand ML, Coates TJ. Depressive symptoms and CD4 lymphocyte decline among HIVinfected men. JAMA. 1993;270:2568-73.

152. Schmitt HJ. A controlled trial of acyclovir for chickenpox in normal children. Eur J Pediatr. 1992. https://doi.org/10.1056/NEJM199111 283252203.

153. Simpson REH. Infectiousness of communicable diseases in the household (measles, chickenpox, and mumps). Lancet. 1952;2:549-54

154. Parmet S, Lynm C, Glass RM. Chickenpox. J Am Med Assoc. 2004;291:906

155. Kulski JK, Norval M. Nucleic acid probes in diagnosis of viral diseases of man. Arch Virol. 1985:83:3-15.

156. Tenover FC. Diagnostic deoxyribonucleic acid probes for infectious diseases. Clin Microbiol Rev. 1988;1:82.

157. Guatelli JC, Gingeras TR, Richman DD. Nucleic acid amplification in vitro: Detection of sequences with low copy numbers and application to diagnosis of human immunodeficiency virus type 1 infection. Clin Microbiol Rev. 1989;2:217-26.

158. Respess RA, Rayfield MA, Dondero TJ. Laboratory testing and rapid HIV assays: applications for HIV surveillance in hard-to-reach populations. Aids LWW. 2001:15:S49-59.

159. Huggett JF, Novak T, Garson JA, Green C, Morris-Jones SD, Miller $R F$, et al. Differential susceptibility of PCR reactions to inhibitors: an important and unrecognised phenomenon. BMC Res Notes. 2008;1:70. https://doi.org/10.1186/1756-0500-1-70.

160. Brinkman JA, Rahmani MZ, Jones WE, Chaturvedi AK, Hagensee ME. Optimization of PCR based detection of human papillomavirus DNA from urine specimens. J Clin Virol. 2004;29:230-40.

161. Kontanis EJ, Reed FA. Evaluation of real-time PCR amplification efficiencies to detect PCR inhibitors. J Forensic Sci. 2006;51:795-804. https://doi.org/10.1111/j.1556-4029.2006.00182.x.

162. Oikarinen S, Tauriainen S, Viskari H, Simell O, Knip M, Virtanen S, et al. PCR inhibition in stool samples in relation to age of infants. J Clin Virol. 2009:44:211-4.

163. Monteiro L, Bonnemaison D, Vekris A, Petry KG, Bonnet J, Vidal R, et al. Complex polysaccharides as PCR inhibitors in feces: Helicobacter pylori model. J Clin Microbiol. 1997:35:995-8. 
164. Schrader C, Schielke A, Ellerbroek L, Johne R. PCR inhibitors-occurrence, properties and removal. J Appl Microbiol. 2012. https://doi.org/ 10.1111/j.1365-2672.2012.05384.x.

165. Kim CH, Khan M, Morin DE, Hurley WL, Tripathy DN, Kehrli M, et al. Optimization of the PCR for detection of Staphylococcus aureus nuc gene in bovine milk. J Dairy Sci. 2001;84:74-83.

166. Akane A, Matsubara K, Nakamura H, Takahashi S, Kimura K. Identification of the heme compound copurified with deoxyribonucleic acid (DNA) from bloodstains, a major inhibitor of polymerase chain reaction (PCR) amplification. J Forensic Sci. 1994;39:13607.

167. Abu Al-Soud W, Rådström P. Effects of amplification facilitators on diagnostic PCR in the presence of blood, feces, and meat. J Clin Microbiol. 2000;38:4463-70

168. Hedman J, Rådström P. Overcoming inhibition in real-time diagnostic PCR. Methods in Mol Biol. 2013;943:17-48. https://doi.org/10.1007/ 978-1-60327-353-4_2.

169. Elwick K, Zeng X, King J, Budowle B, Hughes-Stamm S. Comparative tolerance of two massively parallel sequencing systems to common PCR inhibitors. Int J Legal Med. 2018;132:983-95. https://doi.org/10. 1007/s00414-017-1693-4.

170. Sidstedt M, Jansson L, Nilsson E, Noppa L, Forsman M, Rådström P, et al. Humic substances cause fluorescence inhibition in real-time polymerase chain reaction. Anal Biochem. 2015;487:30-7.

171. Sidstedt M, Steffen CR, Kiesler KM, Vallone PM, Rådström P, Hedman J. The impact of common PCR inhibitors on forensic MPS analysis. Forensic Sci Int Genet. 2019;40:182-91.

172. Tsai Y-L, Olson BH. Rapid method for separation of bacterial DNA from humic substances in sediments for polymerase chain reaction. Appl Environ Microbiol. 1992;58:2292-5.

173. Hu Q, Liu Y, Yi S, Huang D. A comparison of four methods for PCR inhibitor removal. Forensic Sci Int Genet. 2015;16:94-7.

174. Eckhart L, Bach J, Ban J, Tschachler E. Melanin binds reversibly to thermostable DNA polymerase and inhibits its activity. Biochem Biophys Res Commun. 2000;271:726-30.

175. Demeke T, Jenkins GR. Influence of DNA extraction methods, PCR inhibitors and quantification methods on real-time PCR assay of biotechnology-derived traits. Anal Bioanaly Chem. 2010. https://doi. org/10.1007/s00216-009-3150-9.

176. Alaeddini R. Forensic implications of PCR inhibition - a review. Forensic Sci Int Genet. 2012;6:297-305.

177. Bickley J, Short JK, McDowell DG, Parkes HC. Polymerase chain reaction (PCR) detection of Listeria monocytogenes in diluted milk and reversal of PCR inhibition caused by calcium ions. Lett Appl Microbiol. 1996;22:153-8. https://doi.org/10.1111/j.1472-765X.1996.tb01131.x.

178. Saiki R, Scharf S, Faloona F, Mullis K, Horn G, Erlich H, et al. Enzymatic amplification of beta-globin genomic sequences and restriction site analysis for diagnosis of sickle cell anemia. Science. 1985;230:1350-4. https://doi.org/10.1126/science.2999980.

179. Saiki R, Gelfand D, Stoffel S, Scharf S, Higuchi R, Horn G, et al. Primerdirected enzymatic amplification of DNA with a thermostable DNA polymerase. Science. 1988;239:487-91.

180. Ou C-Y, Kwok S, Mitchell SW, Mack DH, Sninsky JJ, Krebs JW, et al. DNA amplification for direct detection of HIV-1 in DNA of peripheral blood mononuclear cells. Science. 1988;239:295-7.

181. McCune JM, Namikawa R, Shih C-C, Rabin L, Kaneshima H. Suppression of HIV infection in AZT-treated SCID-hu mice. Science. 1990;247:564-6.

182. Piatak M, Saag MS, Yang LC, Clark SJ, Kappes JC, Luk KC, et al. High levels of HIV-1 in plasma during all stages of infection determined by competitive PCR. Science. 1993;259:1749-54.

183. Mahony JB. Detection of respiratory viruses by molecular methods. Clin Microbiol Rev. 2008;21:716-47.

184. Higuchi R, Fockler C, Dollinger G, Watson R. Kinetic PCR analysis: Real-time monitoring of DNA amplification reactions. Bio/Technology. 1993;11:1026-30

185. Freeman WM, Walker SJ, Vrana KE. Quantitative RT-PCR: Pitfalls and potential. BioTechniques. 1999. https://doi.org/10.2144/99261 rv01.

186. Compton J. PRODUCT REVIEW Nucleic acid sequence-based amplification. Nature. 1991. https://doi.org/10.1038/350091a0.

187. Notomi T, Okayama H, Masubuchi H, Yonekawa T, Watanabe K, Amino $\mathrm{N}$, et al. Loop-mediated isothermal amplification of DNA. Nucleic Acids Res. 2000;28:63.
188. Matsuda K, Yamaguchi A, Taira C, Sueki A, Koeda H, Takagi F, et al. A novel high-speed droplet-polymerase chain reaction can detect human influenza virus in less than 30min. Clinica Chimica Acta Elsevier. 2012;413:1742-5.

189. Narushima R, Shimazaki T, Takahashi T. Development of a real-time reverse-transcription-PCR method for detection of RD1 14 virus in canine vaccines. Biologicals. 2011;39:89-93.

190. Kim HJ. Validation of the sensitivities of one-step and two-step reverse-transcription PCR methods for detection of viral hemorrhagic septicemia virus (VHSV) IVa isolates from cultured olive flounder in Korea. Aquaculture. 2015;448:359-64.

191. Muyzer G, de Waal EC, Uitterlinden AG. Profiling of complex microbial populations by denaturing gradient gel electrophoresis analysis of polymerase chain reaction-amplified genes coding for $16 \mathrm{~S}$ rRNA. Appl Environ Microbiol. 1993;59:695-700.

192. Yan L, Peng S, Yan P, Zhou J, Teng Q, Li G, et al. Comparison of real-time reverse transcription loop-mediated isothermal amplification and realtime reverse transcription polymerase chain reaction for duck Tembusu virus. J Virol Methods. 2012;182:50-5.

193. Guittré C, Baginski I, le Gall G, Prave M, Trépo C, Cova L. Detection of rabbit haemorrhagic disease virus isolates and sequence comparison of the $\mathrm{N}$-terminus of the capsid protein gene by the polymerase chain reaction. Res Vet Sci. 1995;58:128-32.

194. Hyndman L, Vilcek S, Conner J, Nettleton PF. A novel nested reverse transcription PCR detects bovine viral diarrhoea virus in fluids from aborted bovine fetuses. J Virol Methods. 1998;71:69-76.

195. van Pelt-Verkuil E, Witt R. Principles of PCR. Singapore: Springer; 2019. https://doi.org/10.1007/978-981-13-1604-3_5

196. Potapov V, Ong JL. Examining sources of error in PCR by single-molecule sequencing. PLoS ONE. 2017;12:e0169774. https://doi.org/10.1371/ journal.pone.0169774.

197. Bustin SA. INVITED REVIEW Quantification of MRNA using real-time reverse transcription PCR (RT-PCR): trends and problems. J Mol Endocrinol. 2002;29:23-39.

198. Osman F, Hodzic E, Kwon SJ, Wang J, Vidalakis G. Development and validation of a multiplex reverse transcription quantitative PCR (RT-qPCR) assay for the rapid detection of Citrus tristeza virus, Citrus psorosis virus, and Citrus leaf blotch virus. J Virol Methods. 2015;220:64-75.

199. Shen M, Zhou Y, Ye J, Al-Maskri AA, Kang Y, Zeng S, et al. Recent advances and perspectives of nucleic acid detection for coronavirus. J Pharm Anal. 2020;10:97-101.

200. Corral JE, Hoogenboom SA, Kröner PT, Vazquez-Roque MI, Picco MF, Farraye FA, et al. COVID-19 polymerase chain reaction testing before endoscopy: an economic analysis. Gastrointest Endosc. 2020;92:524-34.

201. Petrillo S, Carrà G, Bottino P, Zanotto E, de Santis MC, Margaria JP, et al. A novel multiplex qRT-PCR assay to detect SARS-CoV-2 infection: high sensitivity and increased testing capacity. Microorganisms. 2020;8:1064.

202. Sohn YJ, Choi JH, Choi YY, Choe YJ, Kim K, Kim YK, et al. Effectiveness of trivalent inactivated influenza vaccines in children during 2017-2018 season in Korea: comparison of test-negative analysis by rapid and RTPCR influenza tests. Int J Infect Dis. 2020;99:199-203.

203. Sakamaki I, Morinaga Y, Tani H, Takegoshi Y, Fukui Y, Kawasuji H, et al. Monitoring of viral load by RT-PCR caused decision making to continue ECMO therapy for a patient with COVID-19. J Infect Chemother. 2020;26:1324-7.

204. Nunes BTD, de Mendonça MHR, de Brito Simith D, Moraes AF, Cardoso CC, Prazeres ITE, et al. Development of RT-qPCR and semi-nested RTPCR assays for molecular diagnosis of hantavirus pulmonary syndrome. PLoS Negl Trop Dis. 2019;13:e0007884. https://doi.org/10.1371/journal. pntd.0007884.

205. Zhang J, Nfon C, Tsai CF, Lee CH, Fredericks L, Chen Q, et al. Development and evaluation of a real-time RT-PCR and a field-deployable RTinsulated isothermal PCR for the detection of Seneca Valley virus. BMC Vet Res. 2019:15:168. https://doi.org/10.1186/s12917-019-1927-4.

206. Chu DKW, Pan Y, Cheng SMS, Hui KPY, Krishnan P, Liu Y, et al. Molecular diagnosis of a novel coronavirus (2019-nCoV) causing an outbreak of Pneumonia. Clin Chem. 2020;66:549-55.

207. Nakagawa K, Lokugamage KG, Makino S. Viral and cellular mRNA translation in Coronavirus-infected cells. Adv Virus Res. 2016;96:165-92. 
208. Michel CJ, Mayer C, Poch O, Thompson JD. Characterization of accessory genes in coronavirus genomes. Virol J. 2020;17:131. https://doi.org/ 10.1186/s12985-020-01402-1.

209. Kopecky-Bromberg SA, Martínez-Sobrido L, Frieman M, Baric RA, Palese P. Severe acute respiratory syndrome Coronavirus Open Reading Frame (ORF) 3b, ORF 6, and nucleocapsid proteins function as interferon antagonists. J Virol. 2007;81:548-57.

210. V'kovski P, Kratzel A, Steiner S, Stalder H, Thiel V. Coronavirus biology and replication: implications for SARS-CoV-2. Nat Rev Microbiol. 2020;19:1-16.

211. Udugama B, Kadhiresan P, Kozlowski HN, Malekjahani A, Osborne M, Li VYC, et al. Diagnosing COVID-19: the disease and tools for detection. ACS Nano. 2020. https://doi.org/10.1021/acsnano.0c02624.

212. Yan Y, Chang L, Wang L. Laboratory testing of SARS-CoV, MERS-CoV, and SARS-CoV-2 (2019-nCoV): current status, challenges, and countermeasures. Rev Med Virol. 2020;30:e2106. https://doi.org/10.1002/rmv.2106.

213. Bestle D, Heindl MR, Limburg $H$, van Lam van T, Pilgram O, Moulton $H$, et al. TMPRSS2 and furin are both essential for proteolytic activation of SARS-CoV-2 in human airway cells. Life Sci Alliance. 2020. https://doi. org/10.26508/lsa.202000786.

214. Bu J, Deng Z, Liu H, Li J, Wang D, Yang Y, et al. Current methods and prospects of coronavirus detection. Talanta. 2021;225:121977.

215. Li Y, Li J, Zhang Y, Dai L, Li L, Liu J, et al. Development of an automatic integrated gene detection system for novel severe acute respiratory syndrome-related coronavirus (SARS-CoV2). Emerg Microb Infect. 2020;9:1489-96. https://doi.org/10.1080/22221751.2020.1782774.

216. Wang P. Combination of serological total antibody and RT-PCR test for detection of SARS-COV-2 infections. J Virol Methods. 2020;283:113919.

217. Corman VM, Landt O, Kaiser M, Molenkamp R, Meijer A, Chu DK, et al. Detection of 2019 novel coronavirus (2019-nCoV) by real-time RT-PCR. Eurosurveillance. 2020;25:2000045. https://doi.org/10.2807/1560-7917. ES.2020.25.3.2000045.

218. Liu HJ, Lee LH, Shih WL, Lin MY, Liao MH. Detection of infectious bronchitis virus by multiplex polymerase chain reaction and sequence analysis. J Virol Methods. 2003;109:31-7.

219. Zhang H, Miller BL. Immunosensor-based label-free and multiplex detection of influenza viruses: State of the art. Biosensors and Bioelectronics. Elsevier Ltd; 2019. p. 111476.

220. Zhao JJ, Cheng D, Li N, Sun Y, Shi Z, Zhu QH, et al. Evaluation of a multiplex real-time RT-PCR for quantitative and differential detection of wild-type viruses and C-strain vaccine of Classical swine fever virus. Vet Microbiol. 2008;126:1-10

221. Luan J, Yuan J, Li X, Jin S, Yu L, Liao M, et al. Multiplex detection of 60 Hepatitis B Virus variants by MALDI-TOF mass spectrometry. Clin Chem. 2009;55(8):1503-9.

222. Bell NM, Lever AML. HIV Gag polyprotein: processing and early viral particle assembly. Trends Microbiol. 2013;21:136-44.

223. Corti D, Langedijk JPM, Hinz A, Seaman MS, Vanzetta F, FernandezRodriguez BM, et al. Analysis of Memory B Cell Responses and Isolation of Novel Monoclonal Antibodies with Neutralizing Breadth from HIV1-Infected Individuals. PLoS ONE. 2010;5:e8805.

224. Zhang W, Evans DH. Detection and identification of human influenza viruses by the polymerase chain reaction. J Virol Methods. 1991;33:165-89.

225. Collins RA, Ko LS, Fung KY, Chan KY, Xing J, Lau LT, et al. Rapid and sensitive detection of avian influenza virus subtype H7 using NASBA. Biochem Biophys Res Commun. 2003;300:507-15.

226. Chomczynski P, Sacchi N. Single-step method of RNA isolation by acid guanidinium thiocyanate-phenol-chloroform extraction. Anal Biochem. 1987;162:156-9.

227. Starick E, Romer-Oberdorfer A, Werner O. Type- and subtype-specific RT-PCR assays for Avian Influenza A Viruses (AIV). J Vet Med Ser B. 2000;47:295-301. https://doi.org/10.1046/j.1439-0450.2000.00386.x.

228. Donofrio JC, Donald Coonrod J, Davidson JN, Betts RF. Detection of influenza $A$ and $B$ in respiratory secretions with the polymerase chain reaction. Genome. 1992:1:263-8.

229. Atmar RL, Baxter BD, Dominguez EA, Taber LH. Comparison of reverse transcription-PCR with tissue culture and other rapid diagnostic assays for detection of type A influenza virus. J Clin Microbiol. 1996;34:2604-6.

230. Spackman E, Senne DA, Myers TJ, Bulaga LL, Garber LP, Perdue ML, et al. Development of a real-time reverse transcriptase PCR assay for type A influenza virus and the avian $\mathrm{H} 5$ and $\mathrm{H} 7$ hemagglutinin subtypes. J Clin Microbiol. 2002;40:3256-60.

231. Payungporn S, Chutinimitkul S, Chaisingh A, Damrongwantanapokin S, Buranathai C, Amonsin A, et al. Single step multiplex real-time RT-PCR for H5N1 influenza A virus detection. J Virol Methods. 2006;131:143-7.

232. Panning M, Eickmann M, Landt O, Monazahian M, Olschläger S, Baumgarte $\mathrm{S}$, et al. Detection of influenza $\mathrm{A}(\mathrm{H} 1 \mathrm{~N} 1) \mathrm{v}$ virus by real-time RT-PCR. Eur Commun Dis Bull. 2009;14:19329. https://doi.org/10.2807/ese.14.36. 19329-en.

233. Selvaraju SB, Selvarangan R. Evaluation of three influenza A and B realtime reverse transcription-PCR assays and a new 2009 H1N1 assay for detection of influenza viruses. J Clin Microbiol. 2010;48:3870-5.

234. Bustin SA. Quantification of mRNA using real-time reverse transcription PCR (RT-PCR): trends and problems. J Mol Endocrinol. 2002;29:23-39.

235. Yao Y, Chen X, Zhang X, Liu Q, Zhu J, Zhao W, et al. Rapid detection of Influenza Virus subtypes based on an integrated centrifugal disc. ACS Sens. 2020;5:1354-62. https://doi.org/10.1021/acssensors.9b02595.

236. Imai M, Ninomiya A, Minekawa H, Notomi T, Ishizaki T, Tashiro M, et al. Development of H5-RT-LAMP (loop-mediated isothermal amplification) system for rapid diagnosis of $\mathrm{H} 5$ avian influenza virus infection. Vaccine. 2006;24:6679-82.

237. Wang H, Cong F, Zeng F, Lian Y, Liu X, Luo M, et al. Development of a real time reverse transcription loop-mediated isothermal amplification method (RT-LAMP) for detection of a novel swine acute diarrhea syndrome coronavirus (SADS-CoV). J Virol Methods. 2018;260:45-8.

238. Kashir J, Yaqinuddin A. Loop mediated isothermal amplification (LAMP) assays as a rapid diagnostic for COVID-19. Med Hypotheses. 2020;141:109786.

239. Lv X, Wang L, Zhang J, Zeng H, Chen X, Shi L, et al. Rapid and sensitive detection of VBNC Escherichia coli O157: H7 in beef by PMAxx and realtime LAMP. Food Control. 2020;115:107292.

240. Shirato K, Semba S, El-Kafrawy SA, Hassan AM, Tolah AM, Takayama I, et al. Development of fluorescent reverse transcription loop-mediated isothermal amplification (RT-LAMP) using quenching probes for the detection of the Middle East respiratory syndrome coronavirus. J Virol Methods. 2018;258:41-8.

241. van Gemen $B$, van Beuningen $R$, Nabbe $A$, van Strijp $D$, Jurriaans $S$, Lens $P$, et al. A one-tube quantitative HIV-1 RNA NASBA nucleic acid amplification assay using electrochemiluminescent (ECL) labelled probes. J Virol Methods. 1994;49:157-67.

242. Saag MS, Holodniy M, Kuritzkes DR, O'Brien WA, Coombs R, Poscher ME, et al. HIV viral load markers in clinical practice. Nat Med. 1996;2:625-9.

243. Romano JW, Williams KG, Shurtliff RN, Ginocchio C, Kaplan M. NASBA technology: Isothermal RNA amplification in qualitative and quantitative diagnostics. Immunol Investig. 1997;26:15-28. https://doi.org/10. 3109/08820139709048912.

244. Keightley MC, Sillekens P, Schippers W, Rinaldo C, George K. Real-time NASBA detection of SARS-associated coronavirus and comparison with real-time reverse transcription-PCR. J Med Virol. 2005;77:602-8. https:// doi.org/10.1002/jmv.20498.

245. Leone $G$, van Schijndel H, van Gemen B, Kramer FR, Schoen CD. Molecular beacon probes combined with amplification by NASBA enable homogeneous, real-time detection of RNA. Nucleic Acids Res. 1998;26:2150-5.

246. Kievits T, van Gemen B, van Strijp D, Schukkink R, Dircks M, Adriaanse H, et al. NASBATM isothermal enzymatic in vitro nucleic acid amplification optimized for the diagnosis of HIV-1 infection. J Virol Methods. 1991;35:273-86.

247. Deiman B, van Aarle P, Sillekens P. Characteristics and applications of Nucleic Acid Sequence-Based Amplification (NASBA). Appl Biochem Biotechnol Part B Mol Biotechnol. 2002. https://doi.org/10.1385/MB: 20:2:163.

248. Boyle DS, Lehman DA, Lillis L, Peterson D, Singhal M, Armes N, et al. Rapid detection of HIV-1 proviral DNA for early infant diagnosis using recombinase polymerase amplification. mBio. 2013;4:e00135.

249. Gall A, Ferns B, Morris C, Watson S, Cotten M, Robinson M, et al. Universal amplification, next-generation sequencing, and assembly of HIV-1 genomes. J Clin Microbiol. 2012;50:3838-44.

250. Lillis L, Lehman D, Singhal MC, Cantera J, Singleton J, Labarre P, et al. Non-instrumented incubation of a recombinase polymerase amplification assay for the rapid and sensitive detection of proviral HIV-1 DNA. 
PLoS ONE. 2014;9:e108189. https://doi.org/10.1371/journal.pone.01081 89.

251. de Oliveira F, Cappy P, Lemée V, Moisan A, Pronier C, Bocket L, et al. Detection of numerous HIV-1/MO recombinants in France. AIDS. 2018:32:1289-99.

252. Smithgall MC, Scherberkova I, Whittier S, Green DA. Comparison of cepheid Xpert Xpress and abbott ID now to Roche cobas for the rapid detection of SARS-CoV-2. J Clin Virol. 2020;128:104428.

253. Basu A, Zinger T, Inglima K, Woo K-M, Atie O, Yurasits L, et al. Performance of Abbott ID NOW COVID-19 rapid nucleic acid amplification test in nasopharyngeal swabs transported in viral media and dry nasal swabs, in a New York City academic institution. J Clin Microbiol. 2020. https://doi.org/10.1101/2020.05.11.089896.

254. Rhoads DD, Cherian SS, Roman K, Stempak LM, Schmotzer CL, Sadri N. Comparison of abbott id now, diasorin simplexa, and CDC fda emergency use authorization methods for the detection of sars-cov-2 from nasopharyngeal and nasal swabs from individuals diagnosed with covid-19. J Clin Microbiol. 2020. https://doi.org/10.1148/radiol.20202 00432.

255. Mitchell SL, George KS. Evaluation of the COVID19 ID NOW EUA assay. J Clin Virol. 2020;128:104429.

256. Amano Y, Cheng Q. Detection of influenza virus: traditional approaches and development of biosensors. Anal Bioanal Chem. 2005. https://doi. org/10.1007/s00216-004-2927-0.

257. Shen Z, Xiao Y, Kang L, Ma W, Shi L, Zhang L, et al. Genomic Diversity of severe acute respiratory syndrome-coronavirus 2 in patients with coronavirus disease. Clin Infect Dis. 2020;71:713-20.

258. Boon ACM, French AMF, Fleming DM, Zambon MC. Detection of influenza a subtypes in community-based surveillance. J Med Virol. 2001;65:163-70. https://doi.org/10.1002/jmv.2016.

259. Bourgeois MA, Oaks JL. Laboratory Diagnosis of Viral Infections. Equine Infectious Diseases: Second Edition. Elsevier Inc;; 2013. p. 132-140.e2

260. Stewart GL, Parkman PD, Hopps HE, Douglas RD, Hamilton JP, Meyer HM. Rubella-virus hemagglutination-inhibition test. N Engl J Med. 1967:276:554-7. https://doi.org/10.1056/NEJM196703092761006.

261. Meijer A, Bosman A, van de Kamp EEHM, Wilbrink B, van Beest Holle MDR, Koopmans M. Measurement of antibodies to avian influenza virus $A(H 7 N 7)$ in humans by hemagg lutination inhibition test. J Virol Methods. 2006;132:113-20.

262. Hilleman MR, Werner JH. Influence of non-specific inhibitor on the diagnostic hemagglutination-inhibition test for influenza. J Immunol. 1953;71:110-7.

263. Black S, Nicolay U, Vesikari T, Knuf M, del Giudice G, Della Cioppa G, et al. Hemagglutination inhibition antibody titers as a correlate of protection for inactivated influenza Vaccines in children. Pediatr Infect Dis J. 2011;30:1081-5.

264. Yoon K-J, Janke BH, Swalla RW, Erickson G. Comparison of a commercial H1N1 enzyme-linked immunosorbent assay and hemagglutination inhibition test in detecting serum antibody against swine influenza viruses. J Vet Diagn Invest. 2004;16(3):197-201.

265. Reina J, Padilla E, Alonso F, Ruiz de Gopegui ER, Munar M, Mari M. Evaluation of a new dot blot enzyme immunoassay (directigen flu A+B) for simultaneous and differential detection of influenza $A$ and $B$ virus antigens from respiratory samples. J Clin Microbiol. 2002;40:3515-7.

266. Cazacu AC, Greer J, Taherivand M, Demmler GJ. Comparison of lateralflow immunoassay and enzyme immunoassay with viral culture for rapid detection of influenza virus in nasal wash specimens from children. J Clin Microbiol. 2003;41:2132-4.

267. Quach C, Newby D, Daoust G, Rubin E, McDonald J. QuickVue influenza test for rapid detection of influenza $A$ and $B$ viruses in a pediatric population. Clin Diagn Lab Immunol. 2002;9:925-6.

268. Lee CY-P, Lin RTP, Renia L, Ng LFP. Serological approaches for COVID-19: epidemiologic perspective on surveillance and control. Front Immunol. 2020:11:879. https://doi.org/10.3389/fimmu.2020.00879/full.

269. Zhang B, Zhou X, Zhu C, Feng F, Qiu Y, Feng J, et al. Immune phenotyping based on neutrophil-to-lymphocyte ratio and lgG predicts disease severity and outcome for patients with COVID-19. medRxiv. 2020. https://doi.org/10.1101/2020.03.12.20035048v1.

270. Long QX, Deng HJ, Chen J, Hu JL, Liu BZ, Liao P, et al. Antibody responses to SARS-CoV-2 in COVID-19 patients: the perspective application of serological tests in clinical practice. medRxiv. 2020. https://doi.org/10.1101/2020.03.18.20038018.

271. Xiao AT, Gao C, Zhang S. Profile of specific antibodies to SARS-CoV-2: the first report. J Infect. 2020;81:147-78.

272. Ahmed SF, Quadeer AA, McKay MR. Preliminary identification of potential vaccine targets for the COVID-19 Coronavirus (SARS-CoV-2) Based on SARS-CoV immunological studies. Viruses. 2020;12:254.

273. Okba NMA, Müller MA, Li W, Wang C, GeurtsvanKessel CH, Corman VM, et al. SARS-CoV-2 specific antibody responses in COVID-19 patients. medRxiv. 2020. https://doi.org/10.1101/2020.03.18.20038059.

274. Delchambre M, Gheysen D, Thinés D, Thiriart $C$, Jacobs E, Verdin E, et al. The GAG precursor of simian immunodeficiency virus assembles into virus-like particles. EMBO J. 1989:8:2653-60.

275. Karacostas V, Nagashima K, Gonda MA, Moss B. Human immunodeficiency virus-like particles produced by a vaccinia virus expression vector. Proc Natl Acad Sci. 1989;86:8964-7.

276. Gheysen D, Jacobs E, de Foresta F, Thiriart C, Francotte M, Thines D, et al. Assembly and release of HIV-1 precursor Pr55gag virus-like particles from recombinant baculovirus-infected insect cells. Cell. 1989;59:103-12.

277. Brangel P, Sobarzo A, Parolo C, Miller BS, Howes PD, Gelkop S, et al. A serological point-of-care test for the detection of igg antibodies against Ebola virus in human survivors. ACS Nano. 2018;12:63-73.

278. Le TT, Chang P, Benton DJ, McCauley JW, lqbal M, Cass AEG. Dual recognition element lateral flow assay toward multiplex strain specific influenza virus detection. Anal Chem. 2017;89:6781-6.

279. Yan X, Zhong W, Tang A, Schielke EG, Hang W, Nolan JP. Multiplexed flow cytometric immunoassay for influenza virus detection and differentiation. Anal Chem. 2005;77:7673-8. https://doi.org/10.1021/ac050 8797.

280. Lee HH, Dineva MA, Chua YL, Ritchie AV, Ushiro-Lumb I, Wisniewski CA. Simple amplification-based assay: a nucleic acid-based point-of-care platform for HIV-1 testing. J Infect Dis. 2010;201:S65-72. https://doi.org/ $10.1086 / 650385$.

281. He Y, Zhang S, Zhang X, Baloda M, Gurung AS, Xu H, et al. Ultrasensitive nucleic acid biosensor based on enzyme-gold nanoparticle dual label and lateral flow strip biosensor. Biosens Bioelectron. 2011;26:2018-24.

282. Tang S, Zhao J, Storhoff JJ, Norris PJ, Little RF, Yarchoan R, et al. Nanoparticle-based biobarcode amplification assay (BCA) for sensitive and early detection of human immunodeficiency type 1 capsid (p24) antigen. JAIDS J Acquir Immune Defic Syndr. 2007;46:231-7.

283. Rohrman BA, Leautaud V, Molyneux E, Richards-Kortum RR. A lateral flow assay for quantitative detection of amplified HIV-1 RNA. PLoS ONE. 2012;7:e45611. https://doi.org/10.1371/journal.pone.0045611.

284. Clark MF, Lister RM, Bar-Joseph M. ELISA techniques. Methods Enzymol. 1986;118:742-66.

285. Luo Q, Huang H, Zou W, Dan H, Guo X, Zhang A, et al. An indirect sandwich ELISA for the detection of avian influenza $\mathrm{H} 5$ subtype viruses using anti-hemagglutinin protein monoclonal antibody. Vet Microbiol. 2009;137:24-30.

286. Zhu M, Gong X, Hu Y, Ou W, Wan Y. Streptavidin-biotin-based directional double Nanobody sandwich ELISA for clinical rapid and sensitive detection of influenza H5N1. J Transl Med. 2014;12:1-10. https://doi.org/10. 1186/s12967-014-0352-5.

287. Watcharatanyatip K, Boonmoh S, Chaichoun K, Songserm T, Woratanti M, Dharakul T. Multispecies detection of antibodies to influenza A viruses by a double-antigen sandwich ELISA. JVirol Methods. 2010;163:238-43.

288. Velumani S, Du Q, Fenner BJ, Prabakaran M, Wee LC, Nuo LY, et al. Development of an antigen-capture ELISA for detection of H7 subtype avian influenza from experimentally infected chickens. J Virol Methods. 2008;147:219-25.

289. Holmström P, Syrjänen S, Laine P, Valle S-L, Suni J. HIV antibodies in whole saliva detected by ELISA and western blot assays. Jo Med Virol. 1990;30:245-8. https://doi.org/10.1002/jmv.1890300403.

290. de La Rica R, Stevens MM. Plasmonic ELISA for the ultrasensitive detection of disease biomarkers with the naked eye. Nat Nanotechnol. 2012;7:821-4.

291. Guo L, Ren L, Yang S, Xiao M, Chang D, Yang F, et al. Profiling early humoral response to diagnose novel coronavirus disease (COVID-19). Clin Infect Dis. 2020;71:778-85. https://doi.org/10.1093/cid/ciaa310. 
292. Woo PCY, Lau SKP, Wong BHL, Tsoi HW, Fung AMY, Kao RYT, et al. Differential sensitivities of severe acute respiratory syndrome (SARS) coronavirus spike polypeptide enzyme-linked immunosorbent assay (ELISA) and SARS coronavirus nucleocapsid protein ELISA for serodiagnosis of SARS coronavirus pneumonia. J Clin Microbiol. 2005;43:3054-8. https:// doi.org/10.1128/JCM.43.7.3054-3058.2005.

293. Zhong L, Chuan J, Gong B, Shuai P, Zhou Y, Zhang Y, et al. Detection of serum IgM and IgG for COVID-19 diagnosis. Sci China Life Sci. 2020. https://doi.org/10.1007/s11427-020-1688-9.

294. Long QX, Deng HJ, Chen J, Hu JL, Liu BZ, Liao P, et al. Antibody responses to SARS-CoV-2 in COVID-19 patients: the perspective application of serological tests in clinical practice. medRxiv. 2020. https://doi. org/10.1101/2020.03.18.20038018.

295. Sapkal G, Shete-Aich A, Jain R, Yadav P, Sarkale P, Lakra R, et al. Development of indigenous IgG ELISA for the detection of anti-SARS-CoV-2 IgG. Indian J Med Res. 2020;151:444-9.

296. Beavis KG, Matushek SM, Abeleda APF, Bethel C, Hunt C, Gillen S, et al. Evaluation of the EUROIMMUN Anti-SARS-CoV-2 ELISA Assay for detection of IgA and IgG antibodies. J Clin Virol. 2020;129:104468.

297. Oh S, Kim J, Tran VT, Lee DK, Ahmed SR, Hong JC, et al. Magnetic nanozyme-linked immunosorbent assay for ultrasensitive Influenza A virus detection. ACS Appl Mater Interfaces. 2018;10:12534-43. https:// doi.org/10.1021/acsami.8b02735.

298. Lu PH, Ma YD, Fu CY, Lee G. A structure-free digital microfluidic platform for detection of influenza a virus by using magnetic beads and electromagnetic forces. Lab Chip. 2020;20:789-97.

299. Su D, Wu K, Krishna VD, Klein T, Liu J, Feng Y, et al. Detection of Influenza a Virus in swine nasal swab samples with a wash-free magnetic bioassay and a handheld giant magnetoresistance sensing system. Front Microbiol. 2019;10:1077. https://doi.org/10.3389/fmicb.2019.01077/full.

300. Wu K, Liu J, Saha R, Su D, Krishna VD, Cheeran MCJ, et al. Magnetic particle spectroscopy for detection of Influenza A virus subtype H1 N1. ACS Appl Mater Interfaces. 2020;12:13686-97. https://doi.org/10.1021/ acsami.0c00815.

301. Wu Z, Zeng T, Guo WJ, Bai YY, Pang DW, Zhang ZL. Digital single virus immunoassay for ultrasensitive multiplex Avian Influenza Virus detection based on fluorescent magnetic multifunctional nanospheres. ACS Appl Mater Interfaces. 2019;11:5762-70.

302. Wang S, Ai Z, Zhang Z, Tang M, Zhang N, Liu F, et al. Simultaneous and automated detection of influenza $A$ virus hemagglutinin $\mathrm{H} 7$ and $\mathrm{H} 9$ based on magnetism and size mediated microfluidic chip. Sens Actuators B Chem. 2020;308:127675

303. Tian S, Yang H, Zhang Z, Du M, Mao G, Ji X, et al. A digital quantification method for the detection of biomarkers on a microfluidic array chip. Sens Actuators B Chem. 2019;298:126851.

304. Virzonis D, Vanagas G, Ramanaviciene A, Makaraviciute A, Barauskas D, Ramanavicius A, et al. Resonant gravimetric immunosensing based on capacitive micromachined ultrasound transducers. Microchimica Acta. 2014;181:1749-57.

305. Makaraviciute A, Ruzgas T, Ramanavicius A, Ramanaviciene A. Antibody fragment immobilization on planar gold and gold nanoparticle modified quartz crystal microbalance with dissipation sensor surfaces for immunosensor applications. Anal Methods. 2014;6:2134-40.

306. Ratautaite V, Plausinaitis D, Baleviciute I, Mikoliunaite L, Ramanaviciene A, Ramanavicius A. Characterization of caffeine-imprinted polypyrrole by a quartz crystal microbalance and electrochemical impedance spectroscopy. Sens Actuators B Chem. 2015;212:63-71.

307. Viter R, Savchuk M, Starodub N, Balevicius Z, Tumenas S, Ramanaviciene $A$, et al. Photoluminescence immunosensor based on bovine leukemia virus proteins immobilized on the $\mathrm{ZnO}$ nanorods. Sens Actuators $\mathrm{B}$ Chem. 2019;285:601-6.

308. Viter R, Savchuk M, latsunskyi I, Pietralik Z, Starodub N, Shpyrka N, et al, Analytical, thermodynamical and kinetic characteristics of photoluminescence immunosensor for the determination of Ochratoxin A. Biosens Bioelectron. 2018;99:237-43.

309. Kausaite-Minkstimiene A, Ramanaviciene A, Ramanavicius A. Surface plasmon resonance biosensor for direct detection of antibodies against human growth hormone. Analyst. 2009;134:2051-7.

310. Kausaite-Minkstimiene A, Ramanaviciene A, Kirlyte J, Ramanavicius A. Comparative study of random and oriented antibody immobilization techniques on the binding capacity of immunosensor. Anal Chem. 2010;82:6401-8.

311. Kausaite-Minkstimiene A, Ramanavicius A, Ruksnaite J, Ramanaviciene A. A surface plasmon resonance immunosensor for human growth hormone based on fragmented antibodies. Anal Methods. 2013;5:4757-63.

312. Morkvenaite-Vilkonciene I, Ramanaviciene A, Kisieliute A, Bucinskas V, Ramanavicius A. Scanning electrochemical microscopy in the development of enzymatic sensors and immunosensors. Biosens Bioelectron. 2019:141:111411.

313. Ramanavicius A, Oztekin Y, Ramanaviciene A. Electrochemical formation of polypyrrole-based layer for immunosensor design. Sens Actuators B Chem. 2014;197:237-43.

314. Ramanavicius A, Finkelsteinas A, Cesiulis H, Ramanaviciene A. Electrochemical impedance spectroscopy of polypyrrole based electrochemical immunosensor. Bioelectrochemistry. 2010;79:11-6.

315. Ramanavicius A, Ryskevic N, Oztekin Y, Kausaite-Minkstimiene A, Jursenas S, Baniukevic J, et al. Immunosensor based on fluorescence quenching matrix of the conducting polymer polypyrrole. Anal Bioanal Chem. 2010;398:3105-13. https://doi.org/10.1007/s00216-010-4265-8.

316. Ramanavicius A, Kurilcik N, Jursenas S, Finkelsteinas A, Ramanaviciene A. Conducting polymer based fluorescence quenching as a new approach to increase the selectivity of immunosensors. Biosens Bioelectron. 2007;23:499-505.

317. Ramanaviciene A, German N, Kausaite-Minkstimiene A, Voronovic J, Kirlyte J, Ramanavicius A. Comparative study of surface plasmon resonance, electrochemical and electroassisted chemiluminescence methods based immunosensor for the determination of antibodies against human growth hormone. Biosens Bioelectron. 2012;36:48-55.

318. Plikusiene I, Maciulis V, Graniel O, Bechelany M, Balevicius S, Vertelis V, et al. Total internal reflection ellipsometry for kinetics-based assessment of bovine serum albumin immobilization on $\mathrm{ZnO}$ nanowires. J Mater Chem C. 2021;9:1345-52.

319. Plikusiene I, Balevicius Z, Ramanaviciene A, Talbot J, Mickiene G, Balevicius S, et al. Evaluation of affinity sensor response kinetics towards dimeric ligands linked with spacers of different rigidity: immobilized recombinant granulocyte colony-stimulating factor based synthetic receptor binding with genetically engineered dimeric analyte derivatives. Biosens Bioelectron. 2020;156:112112.

320. Balevicius Z, Paulauskas A, Plikusiene I, Mikoliunaite L, Bechelany M, Popov A, et al. Towards the application of Al2O3/ZnO nanolaminates in immunosensors: total internal reflection spectroscopic ellipsometry based evaluation of BSA immobilization. J Mater Chem C. 2018;6:8778-83.

321. Balevicius Z, Baleviciute I, Tumenas S, Tamosaitis L, Stirke A, Makaraviciute $A$, et al. In situ study of ligand-receptor interaction by total internal reflection ellipsometry. Thin Solid Films. 2014;517:744-8.

322. Baleviciute I, Balevicius Z, Makaraviciute A, Ramanaviciene A, Ramanavicius $A$. Study of antibody/antigen binding kinetics by total internal reflection ellipsometry. Biosens Bioelectron. 2013;39:170-6.

323. Balevicius Z, Ramanaviciene A, Baleviciute I, Makaraviciute A, Mikoliunaite L, Ramanavicius A. Evaluation of intact- and fragmented-antibody based immunosensors by total internal reflection ellipsometry. Sens Actuators B Chem. 2011;160:555-62.

324. Makaraviciute A, Ramanavicius A, Ramanaviciene A. Development of a reusable protein $\mathrm{G}$ based SPR immunosensor for direct human growth hormone detection in real samples. Anal Methods. 2015;7:9875-84.

325. Baniukevic J, Kirlyte J, Ramanavicius A, Ramanaviciene A. Application of oriented and random antibody immobilization methods in immunosensor design. Sens Actuators B: Chem. 2013;189:217-23.

326. Ramanaviciene A, Virzonis D, Vanagas G, Ramanavicius A. Capacitive micromachined ultrasound transducer (CMUT) for immunosensor design. Analyst. 2010;135:1531-4.

327. Raziq A, Kidakova A, Boroznjak R, Reut J, Öpik A, Syritski V. Development of a portable MIP-based electrochemical sensor for detection of SARSCoV-2 antigen. Biosens Bioelectron. 2021;178:113029.

328. Ramanavicius S, Ramanavicius A. Conducting polymers in the design of biosensors and biofuel cells. Polymers. 2020;13:49.

329. Gronowski AM. Who or what is SHERLOCK? Electron J Int Fed Clin Chem Lab Med. 2018;29:201-4. 
330. Brouns SJJ, Jore MM, Lundgren M, Westra ER, Slijkhuis RJH, Snijders APL, et al. Small CRISPR RNAs guide antiviral defense in prokaryotes. Science. 2008;321:960-4

331. McGinn J, Marraffini LA. Molecular mechanisms of CRISPR-Cas spacer acquisition. Nat Rev Microbiol. 2019;17:7-12.

332. Zhang F, Wen Y, Guo X. CRISPR/Cas9 for genome editing: progress, implications and challenges. Hum Mol Genet. 2014;23:R40-6.

333. Gasiunas G, Barrangou R, Horvath P, Siksnys V. Cas9-crRNA ribonucleoprotein complex mediates specific DNA cleavage for adaptive immunity in bacteria. Proc Natl Acad Sci USA. 2012;109:E2579-86. https://doi. org/10.1073/pnas.1208507109.

334. Sapranauskas R, Gasiunas G, Fremaux C, Barrangou R, Horvath P, Siksnys V. The Streptococcus thermophilus CRISPR/Cas system provides immunity in Escherichia coli. Nucleic Acids Res. 2011;39:9275-82.

335. Sasnauskas G, Siksnys V. CRISPR adaptation from a structural perspective. Curr Opin Struct Biol. 2020;65:17-25.

336. Gasiunas G, Sinkunas T, Siksnys V. Molecular mechanisms of CRISPRmediated microbial immunity. Cell Mol Life Sci. 2014. https://doi.org/10. 1007/s00018-013-1438-6.

337. Wilkinson M, Drabavicius G, Silanskas A, Gasiunas G, Siksnys V, Wigley DB. Structure of the DNA-bound spacer capture complex of a type ii CRISPR-Cas system. Mol Cell Cell Press. 2019;75:90-101.e5.

338. Müller M, Lee CM, Gasiunas G, Davis TH, CradickTJ, Siksnys V, et al. Streptococcus thermophilus CRISPR-Cas9 systems enable specific editing of the human genome. Mol Ther. 2016;24:636-44.

339. Glemzaite M, Balciunaite E, Karvelis T, Gasiunas G, Grusyte M, Alzbutas $G$, et al. Targeted gene editing by transfection of in vitro reconstituted Streptococcus thermophilus cas 9 nuclease complex. RNA Biol. 2015;12:1-4. https://doi.org/10.1080/15476286.2015.1017209.

340. Gasiunas G, Young JK, Karvelis T, Kazlauskas D, Urbaitis T, Jasnauskaite M, et al. A catalogue of biochemically diverse CRISPR-Cas9 orthologs. Nat Commun. 2020;11:5512.

341. Makarova KS, Wolf YI, Iranzo J, Shmakov SA, Alkhnbashi OS, Brouns SJJ, et al. Evolutionary classification of CRISPR-Cas systems: a burst of class 2 and derived variants. Nat Rev Microbiol. 2020;18:67-83.

342. Gootenberg JS, Abudayyeh OO, Kellner MJ, Joung J, Collins JJ, Zhang F. Multiplexed and portable nucleic acid detection platform with Cas 13, Cas12a, and Csm6. Science. 2018;360(6387):439-44.

343. Gootenberg JS, Abudayyeh OO, Lee JW, Essletzbichler P, Dy AJ, Joung $J$, et al. Nucleic acid detection with CRISPR-Cas13a/C2c2. Science. 2017;356:438-42.

344. Chaijarasphong T, Thammachai T, Itsathitphaisarn O, Sritunyalucksana K, Suebsing R. Potential application of CRISPR-Cas12a fluorescence assay coupled with rapid nucleic acid amplification for detection of white spot syndrome virus in shrimp. Aquaculture. 2019;512:734340.

345. Khan H, Khan A, Liu Y, Wang S, Bibi S, Xu H, et al. CRISPR-Cas13a mediated nanosystem for attomolar detection of canine parvovirus type 2 . Chin Chem Lett. 2019;30:2201-4

346. Schindele P, Wolter F, Puchta H. Transforming plant biology and breeding with CRISPR/Cas9, Cas12 and Cas13. FEBS Lett. 2018;592:1954-67. https://doi.org/10.1002/1873-3468.13073\%4010.1002/\%28ISSN\% 291873-3468.reviews.

347. Yan F, Wang W, Zhang J. CRISPR-Cas 12 and Cas 13 : the lesser known siblings of CRISPR-Cas9. Cell Biol Toxicol. 2019. https://doi.org/10.1007/ s10565-019-09489-1.

348. Kellner MJ, Koob JG, Gootenberg JS, Abudayyeh OO, Zhang F. SHERLOCK: nucleic acid detection with CRISPR nucleases. Nat Protoc. 2019;14:2986-3012
349. Qin P, Park M, Alfson KJ, Tamhankar M, Carrion R, Patterson Ul, et al. Rapid and fully microfluidic Ebola virus detection with CRISPR-Cas13a. ACS Sens. 2019:4:1048-54. https://doi.org/10.1021/acssensors.9b00239.

350. Kim D, Lee JY, Yang JS, Kim JW, Kim VN, Chang H. The architecture of SARS-CoV-2 transcriptome. Cell. 2020;181:914-921.e10.

351. Joung J, Ladha A, Saito M, Segel M, Bruneau R, Huang MLW, et al. Pointof-care testing for COVID-19 using SHERLOCK diagnostics. medRxiv. 2020. https://doi.org/10.1101/2020.05.04.20091231.

352. Patchsung M, Jantarug K, Pattama A, Aphicho K, Suraritdechachai S, Meesawat $P$, et al. Clinical validation of a Cas13-based assay for the detection of SARS-CoV-2 RNA. Nat Biomedi Eng. 2020;4:1 140-9. https:// doi.org/10.1038/s41551-020-00603-X.

353. Guo L, Sun X, Wang X, Liang C, Jiang H, Gao Q, et al. SARS-CoV-2 detection with CRISPR diagnostics. Cell Discov. 2020;6:1-4.

354. Metsky HC, Freije CA, Kosoko-Thoroddsen TSF, Sabeti PC, Myhrvold C. CRISPR-based surveillance for COVID-19 using genomically-comprehensive machine learning design. bioRxiv. 2020. https://doi.org/10. 1101/2020.02.26.967026v2.

355. Curti L, Pereyra-Bonnet F, Gimenez CA. An ultrasensitive, rapid, and portable coronavirus SARS-CoV-2 sequence detection method based on CRISPR-Cas12. bioRxiv. 2020. https://doi.org/10.1101/2020.02.29. 971127.

356. Myhrvold C, Freije CA, Gootenberg JS, Abudayyeh OO, Metsky HC, Durbin AF, et al. Field-deployable viral diagnostics using CRISPR-Cas13. Science. 2018:360:444-8.

357. Chen JS, Ma E, Harrington LB, da Costa M, Tian X, Palefsky JM, et al. CRISPR-Cas12a target binding unleashes indiscriminate single-stranded DNase activity. Science. 2018;360:436-9.

358. Teng F, Guo L, Cui T, Wang XG, Xu K, Gao Q, et al. CDetection: CRISPRCas12b-based DNA detection with sub-attomolar sensitivity and single-base specificity. Genome Biol. 2019;20:132. https://doi.org/10. 1186/s13059-019-1742-z.

359. Chen JS, Ma E, Harrington LB, da Costa M, Tian X, Palefsky JM, et al. CRISPR-Cas12a target binding unleashes indiscriminate single-stranded DNase activity. Science. 2018:360(6387):436-9.

360. Burstein D, Harrington LB, Strutt SC, Probst AJ, Anantharaman K, Thomas BC, et al. New CRISPR-Cas systems from uncultivated microbes. Nature. 2017:542:237-41.

361. Harrington LB, Burstein D, Chen JS, Paez-Espino D, Ma E, Witte IP, et al. Programmed DNA destruction by miniature CRISPR-Cas 14 enzymes. Science. 2018;362:839-42.

362. Xiang X, Qian K, Zhang Z, Lin F, Xie Y, Liu Y, et al. CRISPR-cas systems based molecular diagnostic tool for infectious diseases and emerging 2019 novel coronavirus (COVID-19) pneumonia. J Drug Target. 2020;28:727-31.

363. Tao D, Liu J, Nie X, Xu B, Tran-Thi TN, Niu L, et al. Application of CRISPRCas12a enhanced fluorescence assay coupled with nucleic acid amplification for the sensitive detection of African Swine fever virus. ACS Synth Biol. 2020;9:2339-50. https://doi.org/10.1021/acssynbio.0c00057.

\section{Publisher's Note}

Springer Nature remains neutral with regard to jurisdictional claims in published maps and institutional affiliations.

Ready to submit your research? Choose BMC and benefit from:

- fast, convenient online submission

- thorough peer review by experienced researchers in your field

- rapid publication on acceptance

- support for research data, including large and complex data types

- gold Open Access which fosters wider collaboration and increased citations

- maximum visibility for your research: over $100 \mathrm{M}$ website views per year

At BMC, research is always in progress.

Learn more biomedcentral.com/submissions 